\title{
Inter-comparison of source apportionment models for the estimation of wood burning aerosols during wintertime in an Alpine city (Grenoble, France)
}

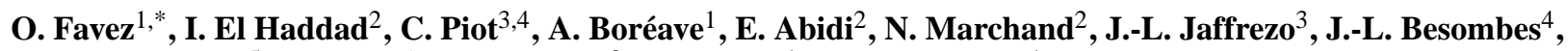 \\ M.-B. Personnaz ${ }^{5}$, J. Sciare ${ }^{6}$, H. Wortham ${ }^{2}$, C. George ${ }^{1}$, and B. D'Anna ${ }^{1}$ \\ ${ }^{1}$ Université Lyon 1, Lyon, 69626, France, CNRS, UMR 5256, IRCELYON, Institut de Recherches sur la Catalyse et \\ l'Environnement de Lyon, Villeurbanne, 69626, France \\ ${ }^{2}$ Universités d'Aix-Marseille-CNRS, UMR 6264, Laboratoire Chimie Provence, Equipe Instrumentation et Réactivité \\ Atmosphérique, Marseille, 13331, France \\ ${ }^{3}$ Université Joseph Fourier-Grenoble 1-CNRS, UMR 5183, Laboratoire de Glaciologie et Géophysique de l'Environnement, \\ Saint Martin d'Hères, 38402, France \\ ${ }^{4}$ Université Savoie-Polytech'Savoie, Laboratoire de Chimie Moléculaire et Environnement, Le Bourget du lac, 73376, France \\ ${ }^{5}$ Association pour le contrôle et la préservation de l'air en région grenobloise (ASCOPARG), Grenoble, 38100, France \\ ${ }^{6}$ Laboratoire des Sciences du Climat et de l'Environnement, CEA-CNRS-UVSQ-IPSL, Gif sur Yvette, 91191, France \\ *now at: INERIS, DRC/CARA/CIME, Parc Technologique Alata, BP2, Verneuil-en-Halatte, 60550, France
}

Received: 26 November 2009 - Published in Atmos. Chem. Phys. Discuss.: 12 January 2010

Revised: 21 May 2010 - Accepted: 27 May 2010 - Published: 16 June 2010

\begin{abstract}
The emission of organic aerosols (OA) in the ambient air by residential wood burning is nowadays a subject of great scientific concern and a growing number of studies aim at apportioning the influence of such emissions on urban air quality. In the present study, results obtained using two commonly-used source apportionment models, i.e., Chemical Mass Balance (CMB, performed with off-line filter measurements) and Positive Matrix Factorization (PMF, applied to Aerosol Mass Spectrometer measurements), as well as using the recently-proposed Aethalometer model (based on the measurement of the aerosol light absorption at different wavelengths) are inter-compared. This work is performed using field data obtained during the winter season (14 to 29 January 2009) at an urban background site of a French Alpine city (Grenoble). Converging results from the different models indicate a major contribution of wood burning organic aerosols $\left(\mathrm{OM}_{\mathrm{wb}}\right)$ to the ambient aerosol organic fraction, with mean $\mathrm{OM}_{\mathrm{wb}}$ contributions to total $\mathrm{OA}$
\end{abstract}

of $68 \%, 61 \%$ and $37 \%$ for the CMB, the Aethalometer and the AMS-PMF models respectively, during the period when the three modelling studies overlapped (12 days). Quantitative discrepancies might notably be due to the overestimation of $\mathrm{OM}_{\mathrm{wb}}$ calculated by the CMB due to the loss of semivolatile compounds from sources to receptor site, as well as to the accounting of oxidized primary wood burning organic $\left(\mathrm{OPOA}_{\mathrm{wb}}\right)$ aerosols within the Oxygenated Organic Aerosol (OOA) PMF-factor. This OOA factor accounts on average for about $50 \%$ of total OM, while non-combustion sources contribute to about $25 \%$ and $28 \%$ of total OM according to the CMB and Aethalometer models respectively. Each model suggests a mean contribution of fossil fuel emissions to total OM of about $10 \%$. A good agreement is also obtained for the source apportionment of elemental carbon (EC) by both the $\mathrm{CMB}$ and the Aethalometer models, with fossil fuel emissions representing on average more than $80 \%$ of total EC. 


\section{Introduction}

Biomass burning is known to emit high amounts of organic aerosols (OA) particularly rich in carcinogenic compounds, such as polycyclic aromatic hydrocarbons (Lewtas et al., 2007). It also represents a significant source of lightabsorbing carbonaceous aerosols, influencing the aerosol radiative forcing as well as the atmospheric photochemistry (Andreae and Gelencsér, 2006). Nevertheless, up to now, public policies dedicated to the reduction of air pollutant emissions mainly concern industrial activities, power plants and transportation, whereas residential wood burning has received little attention in terms of regulation. Furthermore, the use of wood burning for heating purpose is often considered by policy makers as an interesting source of renewable energy. The impact of residential wood burning emissions on air quality may thus increase in the future, at least in western countries where traffic and industrial emissions are currently decreasing. For these reasons, a growing number of scientific studies have recently focused on the apportionment of residential wood burning aerosols in the ambient air of industrialized countries (e.g. Zheng et al., 2002; Kingham et al., 2008; Jeong et al., 2008). For Europe, Puxbaum et al. (2007) reported high contributions of biomass burning aerosols to the organic aerosol fraction during the winter season at various remote sites, which could be mainly attributed to residential wood burning. Significant wood burning emissions were moreover observed in Scandinavian rural sites, in Alpine valleys, as well as in central Europe rural sites (Ricard et al., 2002; Aymoz et al., 2007; Szidat et al., 2007; Sandradewi et al., 2008a; Caseiro et al., 2009; Lanz et al., 2009). For urban environments, Zdráhal et al. (2002) estimated that wood burning emissions accounted for $\sim 35 \%$ of organic carbon (OC) in Ghent, Belgium, during a winter episode. Caseiro et al. (2009), Yttri et al. (2009) and Szidat et al. (2006) also reported high contributions of wood burning organics to OC in Vienna (Austria), Oslo (Norway) and Zürich (Switzerland), i.e., $\sim 20 \%, \sim 30 \%$ and $\sim 40 \%$ respectively for winter time at urban background sites. Finally, Favez et al. (2009) suggested that residential wood burning emissions account for about $20 \pm 10 \%$ of total $\mathrm{PM}_{2.5}$ in such a large city as Paris, France, during wintertime. This non-exhaustive list of studies demonstrates the significant role played by wood burning emissions on air pollution in Europe.

However, most of these studies also pointed out the difficulty to precisely apportion wood burning aerosols in ambient air, as there is currently no standard method to achieve this goal. High concentrations of soluble potassium, organic markers and humic-like substances (HULIS), as well as high organic carbon to elemental carbon ratio (OC/EC) and high water-soluble organic carbon to total organic carbon ratio (WSOC/OC), have been commonly used to evidence biomass burning emissions. In a more quantitative way, levoglucosan and radiocarbon measurements have been used to estimate wood burning organic carbon (e.g. Puxbaum et al., 2007; and Szidat et al., 2006, respectively). Source apportionment models at receptor sites are also more and more used in atmospheric science (Viana et al., 2008). Compared to mono-tracer methods, these models should exhibit higher confidence levels since the apportionment of a particular source is validated by the model ability to describe the total aerosol mass as a linear combination of several identified sources. These source apportionment models are typically composed by two groups: (i) chemical mass balances (CMB), using molecular markers of a-priori-known sources to apportion the total mass (Schauer et al., 1996), and (ii) multiple factor analyses (FA), distributing the total mass among several sources, the number and the nature of which are determined a posteriori (Paatero and Tapper, 1994). While CMB models are widely used with off-line measurements, considerable efforts have been made recently to apply FA to on-line aerosol mass spectrometer (AMS) measurements of the organic fraction (Zhang et al., 2005; Lanz et al., 2007, 2008). In particular, a custom software tool has been developed to analyse AMS organic matrices by means of positive matrix factorizations (PMF) (Ulbrich et al., 2009). Considering the rapid enlargement of the AMS user community, this tool is undoubtedly going to be more and more used in coming years. Finally, an additional model based on the real-time measurement of the aerosol light absorption at several wavelengths has been recently proposed to apportion biomass burning carbonaceous aerosols in ambient air (Sandradewi et al., 2008b, c). This approach, referred here as the Aethalometer model (as it has been used only with this instrument yet), might also become very popular since it is globally less time-consuming and less expensive than CMB- and FA-based models (Sandradewi et al., 2008c).

In the present study, we investigate the chemical composition of the fine aerosol fraction in an Alpine city (Grenoble, France) at wintertime and apply each of these three source apportionment models (CMB, PMF, and Aethalometer model) to our dataset in order to evaluate the contributions of the different OA sources and to compare outputs of these models. Results of this inter-comparison exercise are presented and discussed below, with a specific emphasis on wood burning aerosols which revealed to be the predominant fraction of OA. Each approach is associated with rather large uncertainties, which are calculated in Sects. 4, 5 and 6, describing respectively the CMB model, the Aethalometer model, and the AMS-PMF approach. Depending on the model, these uncertainties are mainly related to sampling artifacts, to instrumental biases, and/or to the validity of hypotheses made for the calculation of the different source contributions. For each approach, the choice of the best solution among those calculated by the model is partly dependent on the user subjectivity. Best solutions chosen and presented in Sects. 4 to 6 are mainly considered for comparison purposes (e.g. Sect. 7). However, main conclusions addressed in the present paper are still valid when considering extreme values of the uncertainty ranges. 
Such an inter-comparison is particularly interesting in the current context, revisiting the traditional definitions of primary and secondary organic aerosol (Donahue et al., 2009, and references therein). It should be mentioned that the AMS-PMF and Aethelometer models consider the entire ambient OA, while the CMB approach is based only on a small fraction of the OA mass and implicitly considers the conservation of organic markers-to-OC ratios from sources to receptor site. In other words the $\mathrm{CMB}$ approach is blind to chemical transformations of (semi-volatile) primary organic aerosols (POA) and apportions the whole mass of carbon emitted by primary sources whatever the chemical state of POA (unreacted or reacted). Meanwhile, secondary organic aerosols (SOA) are treated as an increase of the carbon mass and thus correspond to the traditional definition of SOA. For the AMS-PMF approach, chemical aging of POA is taken into consideration and source apportionment of primary sources refers very likely to the unreacted fraction of POA (Donahue et al. 2009).

\section{Experimental}

\subsection{Sampling site, sampling strategy and meteorological conditions}

Results presented here were obtained from 14 to 29 January 2009 at an urban station ("Les Frênes") of the local air quality monitoring network, considered as representative of Grenoble background air pollution (www.atmo-rhonealpes. org). Greater Grenoble, comprising more than half a million inhabitants, is by far the most densely populated urban area of the French Alps. Closely surrounded by three mountainous massifs, this urban area is situated about $220 \mathrm{~m}$ a.s.1. (above see level). Besides traffic and residential emissions, main industrial activities responsible for pollutant emissions include a cement and two power plants, notably making use of trash-wood.

$\mathrm{PM}_{2.5}$ aerosols were collected on $150 \mathrm{~mm}$-diameter preheated (for $2 \mathrm{~h}$ at $500{ }^{\circ} \mathrm{C}$ ) quartz fiber filters (Whatman QMA) using high volume samplers (HiVol, Digitel DA80 model) at a flow rate of $30 \mathrm{~m}^{3} \mathrm{~h}^{-1}$. Aerosols were also collected on pre-heated $25 \mathrm{~mm}$-diameter quartz fiber filters (Whatman QMA) using a Dekati 13-stage low pressure cascade impactor (LPI) at a flow rate of $301 \mathrm{~min}^{-1}$. These aerosol samples were collected on a 12-h timescale for HiVol filters (06:00 to 18:00 UT, and 18:00 to 06:00 UT, total number of 31 samples) and on a 24-h timescale (06:00 to 06:00 UT, total number of 13 samples) for LPI filters. The chemical composition of fine aerosols was also investigated every $3 \mathrm{~min}$ using an Aerosol Mass Spectrometer (AMS, Aerodyne). This instrument allows real-time measurement of non-refractory components (NR) of the $\mathrm{PM}_{1}$ aerosol fraction using flash vaporization under high vacuum, electron impact ionization, and mass spectrometry. Black carbon (BC) concentrations and aerosol absorption coefficients $\left(b_{\text {abs }}\right)$ were obtained every 5 min using a 7-wavelength Aethalometer (Magee Scientific) equipped with a $\mathrm{PM}_{2.5}$ cutoff inlet. It is worth mentioning here that, in the present paper, the term "BC" is used when referring to data obtained using (optical) Aethalometer measurements, whereas the term "EC" is used when referring to data obtained using (thermooptical) filter analyses. The aerosol size distribution (mobility diameters from 11 to $1083 \mathrm{~nm}$ ), was investigated using a Scanning Mobility Particle Sizer system (SMPS, L-DMA and CPC5403, GRIMM). Finally, 15 min-averaged $\mathrm{NO}_{\mathrm{x}}$ and $\mathrm{PM}_{2.5}$ concentrations were also measured with the standard equipment of the air quality monitoring network, including a Tapered Element Oscillating Microbalance equipped with a Filter Dynamic Measurement System (TEOM-FDMS) for $\mathrm{PM}_{2.5}$.

During the campaign, hourly mean temperature ranged from $-7{ }^{\circ} \mathrm{C}$ to $+14^{\circ} \mathrm{C}$ (mean value of $4 \pm 4{ }^{\circ} \mathrm{C}$ ). Wind speeds were generally below $2 \mathrm{~m} \mathrm{~s}^{-1}$, except during some low pressure system episodes (with duration on the order of $24 \mathrm{~h}$ ) with higher wind speeds and precipitation. These meteorological conditions are representative of those prevailing during the winter season in Grenoble, and more generally in Alpine valleys. Due to low wind speeds and to the local geography, aerosols investigated here were assumed to be mainly emitted and transformed on a local scale.

\subsection{Off-line chemical analyses}

The carbonaceous content of HiVol and LPI samples were analyzed for EC and OC using a Thermo-Optical Transmission (TOT) method on a Sunset Lab analyzer (Birch and Cary, 1996; Aymoz et al., 2007). We used the recently developed EUSAAR2 temperature program proposed by Cavalli et al. (2010). Briefly, it includes temperature from 200 to $650{ }^{\circ} \mathrm{C}$ for the analysis of $\mathrm{OC}$ in $100 \% \mathrm{He}$, and from 500 to $850{ }^{\circ} \mathrm{C}$ for the analysis of $\mathrm{EC}$ in $98 \% \mathrm{He}+2 \% \mathrm{O}_{2}$. The NIOSH protocol (NIOSH, 1996) has also been used for CMB modelling purpose since most of the source profiles available in the literature were acquired according to this protocol.

Organic markers were quantified using gas chromatography mass spectrometry (GC/MS), following the method used by El Haddad et al. (2009). Briefly, filter samples were extracted with a dichloromethane/acetone mix and reduced to a volume of $500 \mu \mathrm{L}$. The remaining volumes were split into two fractions. The first fraction was directly injected for the quantification of linear alkanes, polycyclic aromatic hydrocarbons (PAHs) and hopanes. The second fraction $(50 \mu \mathrm{L})$ was derivatized for $2 \mathrm{~h}$ at $70^{\circ} \mathrm{C}$ before GC-MS analysis, allowing the silylation of hydroxyl groups and the quantification of levoglucosan and others polar organic markers (e.g. methoxyphenols, cholesterol, saturated and unsaturated carboxylic acids). The two fractions were analysed under the same GC-MS conditions, using a Thermo Trace GC 2000 gas chromatograph coupled to a Polaris Q ion trap mass 
Table 1. Organic marker concentrations $\left(\mathrm{ng} \mathrm{m}^{-3}\right)$ in $\mathrm{PM}_{2.5}$ - average (min-max).

\begin{tabular}{|c|c|c|c|}
\hline \multicolumn{4}{|c|}{ n-alkanes } \\
\hline n-pentacosane $e^{-, a}$ & $2.26(0.241-4.91)$ & n-nonacosane $\mathrm{e}^{*, \mathrm{~b}}$ & $1.77(0.287-3.82)$ \\
\hline n-hexacosane $e^{-, b}$ & $1.57(0.148-3.23)$ & n-triacontane ${ }^{*, a}$ & $0.582(0.144-1.39)$ \\
\hline n-heptacosane*,b & $1.89(0.279-3.74)$ & $\mathrm{n}$-hentriacontane ${ }^{*, a}$ & $1.25(0.169-3.27)$ \\
\hline n-octacosane $e^{*, a}$ & $1.62(0.219-2.94)$ & n-dotriacontane $\mathrm{e}^{-, \mathrm{a}}$ & $0.227(0.128-0.762)$ \\
\hline \multicolumn{4}{|c|}{ polycyclic aromatic hydrocarbons } \\
\hline Retene $^{-, c}$ & $0.242(0.057-0.629)$ & Indeno[1,2,3-cd]fluoranthene $e^{-, d}$ & $0.278(0.016-0.750)$ \\
\hline benzo[b,k]fluoranthene $\mathrm{e}^{-, \mathrm{a}}$ & $1.89(0.153-4.89)$ & Indeno[1,2,3-cd]pyrene ${ }^{*, a}$ & $0.696(0.049-2.08)$ \\
\hline benzo[j]fluoranthene ${ }^{-, a}$ & $0.201(0.024-0.661)$ & dibenzoanthracene ${ }^{-, \mathrm{a}}$ & $0.322(0.034-1.29)$ \\
\hline benzo[e]pyrene ${ }^{*, a}$ & $0.859(0.072-2.16)$ & Benzo-ghi-perylene ${ }^{*, a}$ & $0.513(0.042-1.39)$ \\
\hline Hopanes & & & \\
\hline trisnorneohopane $\mathrm{e}^{-, \mathrm{e}}$ & $0.058(0.012-0.443)$ & $17 \alpha(\mathrm{H})-21 \beta(\mathrm{H})-$ hopane ${ }^{*, \mathrm{a}}$ & $0.151(0.027-0.319)$ \\
\hline $17 \alpha(\mathrm{H})$-trisnorhopane $\mathrm{e}^{-, \mathrm{e}}$ & $0.051(0.011-0.196)$ & $17 \alpha(\mathrm{H})-21 \beta(\mathrm{H})-22 \mathrm{~S}-$ homohopane ${ }^{*, \mathrm{e}}$ & $0.062(0.018-0.204)$ \\
\hline $17 \alpha(\mathrm{H})-21 \beta(\mathrm{H})$-norhopane ${ }^{*, \mathrm{e}}$ & $0.227(0.029-0.448)$ & $17 \alpha(\mathrm{H})-21 \beta(\mathrm{H})-22 \mathrm{R}$-homohopane ${ }^{-, \mathrm{e}}$ & $0.035(0.013-0.142)$ \\
\hline \multicolumn{4}{|c|}{ Anhydrous sugars } \\
\hline $\operatorname{mannosan}^{-, \mathrm{a}}$ & $70.6(10.3-261)$ & levoglucosan*,a & $815(108-2550)$ \\
\hline \multicolumn{4}{|c|}{ Sterols } \\
\hline cholesterol $^{-, \mathrm{a}}$ & $0.243(0.044-0.603)$ & $\beta$ - sitosterol $^{-, \mathrm{a}}$ & $18.3(2.43-47.3)$ \\
\hline
\end{tabular}

- Compounds not included in the CMB modelling; * compounds included in the CMB modelling.

The quantification of the organic compounds is based on the response factors of a authentic standards, ${ }^{b}$ average of alkanes with the closer carbon number, ${ }^{\mathrm{c}}$ phenanthrene, ${ }^{\mathrm{d}} 7$ Indeno[1,2,3-cd]pyrene, ${ }^{\mathrm{e}} 17 \alpha(\mathrm{H})-21 \beta(\mathrm{H})$-hopane.

spectrometer operating in the electron impact mode. GC-MS response factors were determined using authentic standards or compounds with analogous chemical structures (see Table 1). GC-MS measurements are only available for samples collected from 18 January onwards, representing a total number of 24 data points

Levoglucosan concentrations were also measured using liquid chromatography - electrospray ionisation - tandem mass spectrometry (LC-ESI-MS ${ }^{2}$ ), as described in Piot et al. (2010). Briefly, prior to analyses, filter samples were extracted into $15 \mathrm{~mL}$ of ultrapure water by $30 \mathrm{~min}$ short vortex agitation, and then filtered using Acrodisc filters with a porosity of $0.2 \mu \mathrm{m}$ (Pall, Gelmann). Liquid chromatography was carried out using a Carbopac PA-1 anion-exchange analytical column $(250 \mathrm{~mm} \times 4 \mathrm{~mm}$, Dionex $)$ coupled with a Carbopac PA-1 guard column $(50 \mathrm{~mm} \times 4 \mathrm{~mm}$, Dionex $)$ with $0.5 \mathrm{mM}$ sodium hydroxide eluant (prepared from a $50 \%$ w/w - NaOH solution, J. T. Baker). The analytical detector was an atmospheric pressure ionisation 3-D quadrupole ion trap mass spectrometer (LCQ Fleet MS, Thermo Fisher Scientific) in negative ion mode. LC-ESI-MS ${ }^{2}$ measurements are available for all HiVol filter samples. The same extracts were also used for the analysis of major ionic species (including $\mathrm{NO}_{3}^{-}, \mathrm{SO}_{4}^{2-}, \mathrm{Cl}^{-}$and $\mathrm{NH}_{4}^{+}$) using ion chromatography, and for the analysis of water-soluble organic carbon (WSOC) using a total organic carbon analyzer, as described in Jaffrezo et al. $(1998,2005)$ respectively.

A detailed paper devoted to the comparison of GC and LC analytical methods for levoglucosan and other anhydride sugars is actually in preparation (Piot et al.). For levoglucosan, the two different techniques (i.e., LC-ESI-MS ${ }^{2}$ and GC-MS) shows a very good consistency (slope $=0.97$, $\left.r^{2}=0.91\right)$.

\subsection{Aethalometer measurements}

Aerosol absorption coefficients $\left(b_{\mathrm{abs}}\right)$ were obtained every $5 \mathrm{~min}$ at seven different wavelengths (370, 470, 520, 590, 660,880 and $950 \mathrm{~nm}$ ) using a Magee Scientific Aethalometer (model AE-31) equipped with a $\mathrm{PM}_{2.5}$ cut-off inlet. This instrument was operating at a flow rate of $51 \mathrm{~min}^{-1}$ in an automated mode, under which the filter tape advances when the attenuation at $370 \mathrm{~nm}$ reaches 75 .

Due to the methodology used within the Aethalometer (filter-based measurement), absorption coefficients directly obtained from this instrument are affected by various sampling and analytical artefacts (mostly referred as multiple scattering and shadowing effects) which need to be carefully corrected (Weingartner et al., 2003; Arnott et al., 2005). The importance of these artefacts notably depends on the aerosol 
chemical composition and size distribution, affecting light scattering. In the present work, the correction procedure introduced by Weingartner et al. (2003) was applied to our dataset as follows:

$b_{\text {abs, } \lambda, t}=\frac{b_{\text {aeth, } \lambda, t}}{2.14 \times \mathrm{R}(\mathrm{ATN})_{\lambda, t}}$

where, at a given time $(t)$ and a given wavelength $(\lambda)$, $b_{\text {abs, } \lambda, t}$ and $b_{\text {aeth, }, \lambda, t}$ correspond to the corrected absorption coefficient and the raw absorption coefficient respectively. The constant 2.14 stands for multiple scattering of the light beam at the filter fibres in the unloaded filter. Finally, $\mathrm{R}(\mathrm{ATN})_{\lambda, t}$ describes the decrease of the latter artefact with the gradual accumulation of particles on/in the filter (i.e., correction of the shadowing effect). $\mathrm{R}(\mathrm{ATN})_{\lambda, t}$ was determined according to the following equation:

$\mathrm{R}(\mathrm{ATN})_{\lambda, t}=\left(\frac{1}{f_{\lambda}}-1\right) \times \frac{\ln \left(\mathrm{ATN}_{\lambda, t}\right)-\ln (10)}{\ln (50)-\ln (10)}+1$

where $\operatorname{ATN}_{\lambda, t}$ corresponds to the light attenuation (i.e., $\left\{100 \times\left(\ln \left(\mathrm{I}_{0} / \mathrm{I}\right)\right\}\right)$ measured by the Aethalometer at a given time and a given wavelength, and $f_{\lambda}$ allows for the correction of the instrumental error that occurs when the shadowing effect is disregarded. Based on Sandradewi et al. (2008a) and Yang et al. (2009), the latter parameter was determined by minimizing the difference between the ratio of absorption coefficients and the ratio of aerosol mass concentrations ( $\mathrm{PM}_{2.5}$ obtained from TEOM-FDMS measurements) before and after filter tape advancements. The overall uncertainty of absorption coefficients calculated this way is on the order of $20 \%$. Nevertheless, this uncertainty is expected to affect measurements at each wavelength in a relatively similar way, so that a highest confidence level is assumed for the spectral shape of light absorption.

Aethalometer measurements were also used to assess black carbon (BC) concentrations at a high time resolution. However, $\mathrm{BC}$ mass loadings were not directly obtained from the Aethalometer software. Alternatively, $b_{\mathrm{abs}}, 950 \mathrm{~nm}$ were computed as a function of EC loadings measured on HiVol filters, and a specific Mass Absorption Efficiency (MAE) of $4.8 \pm 0.9 \mathrm{~m}^{2} \mathrm{~g}^{-1}$ was obtained from this linear regression $\left(r^{2}=0.94\right)$. This value is slightly higher than that recommended by Bond and Bergstrom (2006) at this wavelength for fresh soot $\left(\sim 4.3 \pm 0.6 \mathrm{~m}^{2} \mathrm{~g}^{-1}\right)$. This could be attributed to a possible encapsulation of soot particle by organic/inorganic compounds and to the presence of $\mathrm{BC}$ from wood burning emissions $\left(\mathrm{BC}_{\mathrm{wb}}\right)$, both leading to an increase of $\mathrm{BC}$ mass absorption efficiency (Liousse et al., 1993; Bond and Bergstrom, 2006; Lack et al., 2008). This MAE value was then used to estimate BC loadings every $5 \mathrm{~min}$ from the $b_{\mathrm{abs}}, 950 \mathrm{~nm}$ dataset. Finally, submicron $\mathrm{BC}$ concentrations $\left(\mathrm{BC}_{\mathrm{PM} 1}\right)$ were estimated based on results obtained from LPI measurements, and represent $90 \pm 4 \%$ of $\mathrm{BC}_{\mathrm{PM} 2.5}$.

\subsection{AMS measurements}

A time-of-flight (c-TOF,Tofwerk) Aerodyne Aerosol Mass Spectrometer (AMS) was employed during the campaign. The methodology used within c-ToF AMS is fully described by Drewnick et al. (2005). Briefly, aerosol particles are sampled through a critical orifice (diameter $100 \mu \mathrm{m}$ ) that maintains a sample flow of about $80 \mathrm{~cm}^{3} \mathrm{~min}^{-1}$. They are then focused by an aerodynamic lens assembly as a narrow beam into a vacuum chamber. A mechanical chopper successively allows all particles (beam open), no particle (beam closed) and a packet of particles (beam chopped) to pass this chamber, where aerosols are accelerated according to their vacuum aerodynamic diameter $\left(D_{\mathrm{va}}\right)$. Just before the detection region, non-refractory (NR) components are flash-vaporized on a hot surface $\left(\sim 600^{\circ} \mathrm{C}\right)$ and ionized by electron impact $(70 \mathrm{ev})$. Resultant positively charged ions are then guided into the time-of-light mass spectrometer, allowing unit mass resolution on a 3 min timescale. Due to the geometry of the inlet, only submicron aerosols (NR-PM 1 ) can be accurately analysed.

Results presented here were primarily obtained using the mass spectrum (MS) mode. In this mode, the chopper alternates between beam open and closed positions while the mass spectrometer scans across $m / z 4$ to 301 . The time series of major species (i.e., organic matter, ammonium, sulphate, nitrate and chloride) were determined from total mass spectra by application of the "fragmentation table" introduced by Allan et al. (2004) and using the Squirrel analysis software (v1.43). This methodology allows evaluating the contribution of different species to $\mathrm{m} / \mathrm{z}$ signals based on laboratoryderived fragmentation ratios of the pure species and knowledge of isotopic ratios of the various atoms.

The NR-PM 1 components were quantified using collection efficiencies (CE) of 0.5 typical for dry particles (Matthew et al., 2008), as the relative humidity in the inlet line was always below $40 \%$. The ionization efficiency (IE) of nitrate was determined using pure ammonium nitrate particles, while for all other species relative ion efficiencies (RIE) proposed from previous laboratory studies (Allan et al., 2004, and references therein) were used (i.e., 1.1 for $\mathrm{NO}_{3}^{-}, 1.2$ for $\mathrm{SO}_{4}^{2-}, 4.0$ for $\mathrm{NH}_{4}^{+}, 1.3$ for $\mathrm{Cl}^{-}$, and 1.4 for $\mathrm{OM}$ ).

The accuracy of the calculations presented above is strengthened by the good correlation obtained for the scatterplot of $\left\{\mathrm{NR}-\mathrm{PM}_{1}+\mathrm{BC}_{\mathrm{PM} 1}\right\}$ versus SMPS total volume measurements. For this inter-comparison exercise, total $\mathrm{PM}_{1}$ concentrations are assumed to correspond to the sum of NR$\mathrm{PM}_{1}$ components measured by the AMS and of $\mathrm{BC}_{\mathrm{PM} 1} \mathrm{ob}-$ tained from the Aethalometer. These mass concentrations are then compared to volume concentrations obtained from SMPS measurements for the same size range. A satisfactory correlation is obtained between the two datasets $\left(r^{2}=0.91\right.$, for $15 \mathrm{~min}$ average data). Moreover, the slope of this linear regression (i.e., 1.43) is only slightly lower than the mean aerosol density estimated $\left(\rho_{\text {est }}=1.50 \pm 0.05 \mathrm{~g} \mathrm{~cm}^{-3}\right)$ for this 


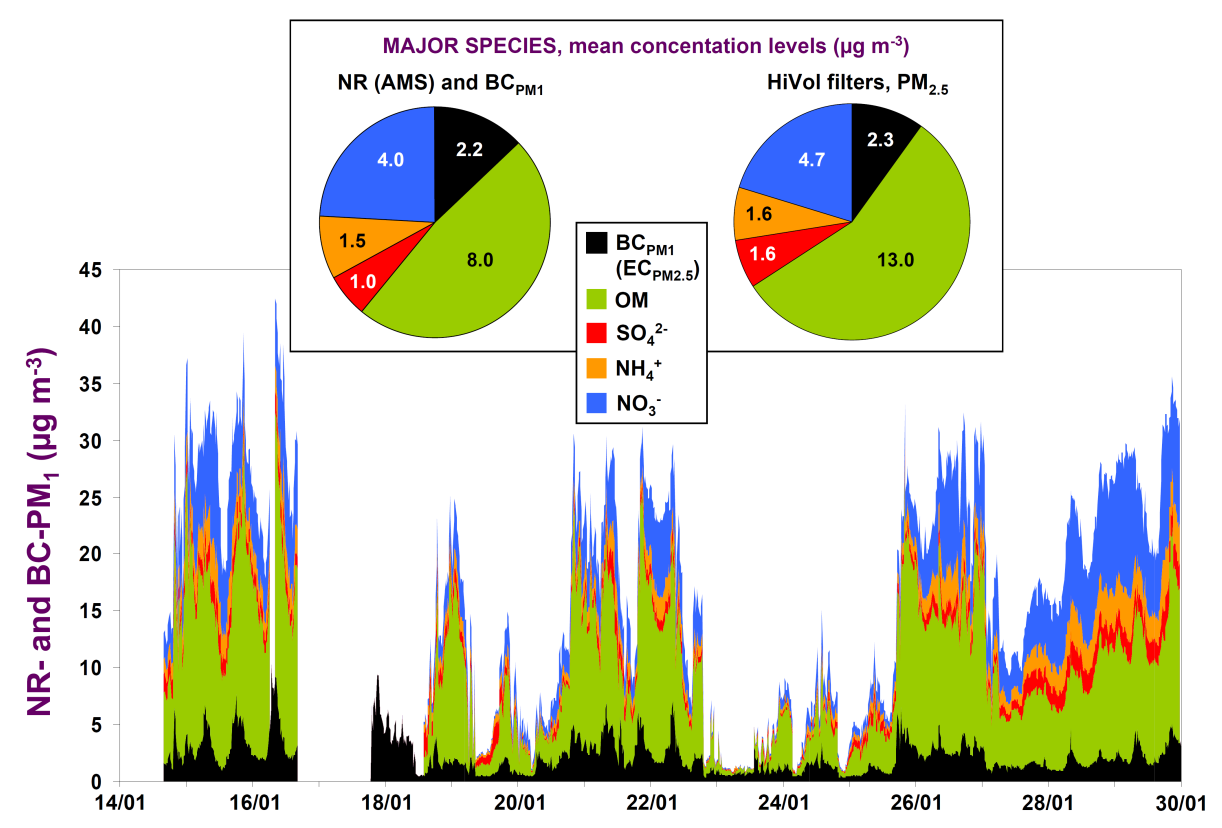

Fig. 1. Time series and mean concentration levels of the main components of the fine aerosol fraction during the period of study. Due to technical issues, AMS measurements are not available from 16/01 to 18/01. Mean $\mathrm{PM}_{2.5}$ concentrations and $\mathrm{BC}$ PM1 were calculated during the same periods than AMS measurements (upper panel).

campaign using AMS/Aethalometer measurements and specific densities of $\sim 1.2$ for organic species, $\sim 1.7$ for ammonium nitrate, and $\sim 1.8$ for ammonium sulphate and BC (based on Turpin and Li, 2001; Park et al., 2004).

\section{Aerosol chemical composition}

Figure 1 shows the time series of the main submicron aerosol components, i.e., organic matter, nitrate, sulphate, ammonium (obtained from AMS measurements) and $\mathrm{BC}_{\mathrm{PM} 1}$. Hourly-mean $\mathrm{PM}_{1}$ loadings, estimated as the sum of these compounds, vary from $\sim 1 \mu \mathrm{g} \mathrm{m}^{-3}$, during low pressure systems associated with rain, to $\sim 40 \mu \mathrm{g} \mathrm{m}^{-3}$ during typical wintertime thermal inversions. Independently of these meteorological conditions, submicron particles are mainly composed of carbonaceous material, with $\mathrm{OM}$ and $\mathrm{BC}$ constituting on average $47 \%$ and $16 \%$ respectively of the $\left\{\mathrm{BC}+\mathrm{OM}+\mathrm{NO}_{3}^{-}+\mathrm{SO}_{4}^{2-}+\mathrm{NH}_{4}^{+}\right\}$sum. Among inorganic aerosols, ammonium nitrate largely dominates over ammonium sulphate, as indicated by the mean $\mathrm{NO}_{3}^{-} / \mathrm{SO}_{4}^{2-}$ ratio of about 4. Similar results are obtained from the analyses of HiVol filters for the $\mathrm{PM}_{2.5}$ aerosol fraction (Fig. 1).

Results from LPI samplings indicate that about $75 \%$ of $\mathrm{OC}_{\mathrm{PM} 10}$ - and about $82 \%$ of $\mathrm{OC}_{\mathrm{PM} 2.5}$ - are comprised in the $\mathrm{PM}_{1}$ fraction (Fig. 2). It should be noted that this OC size distribution was strikingly constant all along the campaign (standard deviation of $\pm 3 \%$, for 24-h samplings). Furthermore, a mean OC-to-OM conversion factor of $1.78 \pm 0.17$ is obtained from the comparison between $\mathrm{PM}_{1}$ AMS and LPI

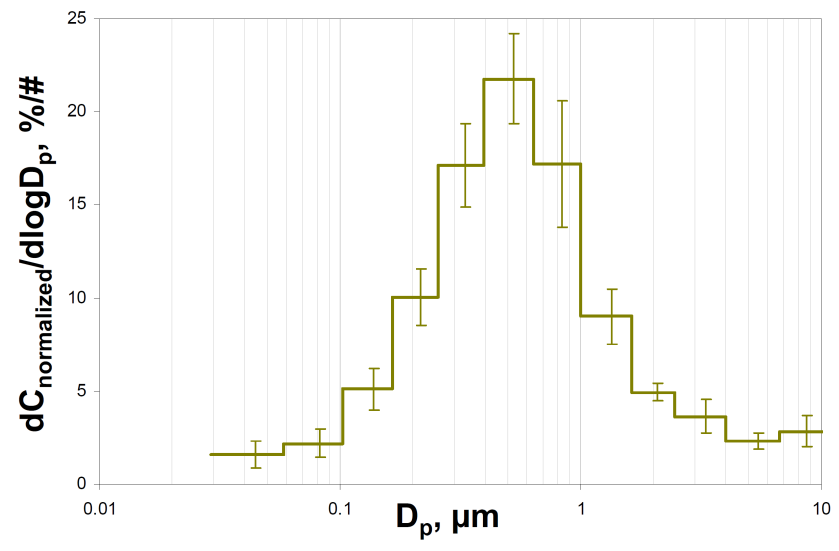

Fig. 2. Averaged OC-size-distribution (obtained from the 24-h LPI measurements, error bars correspond to one standard deviation).

measurements $\left(r^{2}=0.90\right)$. This value suggests relatively high contributions of highly oxidized aerosols, as previous studies reported OC-to-OM conversion factors ranging from 1.21.4 for hydrogenated organic aerosols to $2.0-2.2$ for oxygenated organic aerosols (e.g. Turpin and Lim, 2001; Aiken et al., 2008). An OC-to-OM conversion factor of $\sim 1.8$ is also in good agreement with the mean WSOC/OC ratio of $62 \pm 9 \%$ obtained from the analysis of HiVol filters (data not shown). The importance of submicron (water-soluble) oxidized organic aerosols observed in the present study might be mainly attributed to secondary processes and/or biomass burning emissions. 
Table 2. Selected CMB results obtained using the five selected biomass burning (BB) profiles.

\begin{tabular}{|c|c|c|c|c|c|c|}
\hline Profiles & $\frac{\text { calculated Levoglu cos an }}{\text { measured Levoglu } \cos \text { an }}^{\mathrm{a}}$ & $\frac{\text { calculated EC }}{\text { measured EC }}^{a}$ & $\frac{\mathrm{BB} \mathrm{OC}}{\text { total OC }}$ & $\frac{\text { vehicular OC }}{\text { total OC }}^{\mathrm{a}}$ & $\begin{array}{c}\text { Chi } \\
\text { square }\end{array}$ & references \\
\hline BBAHW & $0.97 \pm 0.08$ & $1.15 \pm 0.31$ & $0.69 \pm 0.21(2)^{b}$ & $0.09 \pm 0.03$ & 0.97 & Fine et al., 2002 \\
\hline BBAR4 & $0.97 \pm 0.10$ & $1.27 \pm 0.50$ & $1.02 \pm 0.34(2)^{\mathrm{b}}$ & $0.07 \pm 0.03$ & 1.74 & Sheesley et al., 2007 \\
\hline BBAR5 & $1.01 \pm 0.08$ & $0.95 \pm 0.35$ & $0.68 \pm 0.22(13)^{b}$ & $0.08 \pm 0.03$ & 1.15 & Sheesley et al., 2007 \\
\hline BBACO & $0.92 \pm 0.17$ & $1.14 \pm 0.30$ & $1.03 \pm 0.34(15)^{\mathrm{b}}$ & $0.10 \pm 0.03$ & 1.01 & Fine et al., 2004 \\
\hline BBECO & $0.27 \pm 0.15$ & $1.51 \pm 0.37$ & $0.27 \pm 0.13(0)^{\mathrm{b}}$ & $0.09 \pm 0.03$ & 4.87 & Schmidl et al., 2008 \\
\hline
\end{tabular}

a Average \pm standard deviation.

${ }^{b}$ Number of samples for which BBOC/OC ratio exceeds 1 .

A significant contribution of biomass burning emissions can be directly evidenced by high levoglucosan concentrations $\left(\sim 0.8 \mu \mathrm{g} \mathrm{m}^{-3}\right.$ on average) as well as high levoglucosan/OC ratios (median value of 0.09). For biomass burning emissions, levoglucosan-to-OC conversion factors typically range from 5 to 12 (Puxbaum et al., 2007, and references therein). Even when using a low value of 5, wood burning $\mathrm{OC}\left(\mathrm{OC}_{\mathrm{wb}}\right)$ accounts for $55 \%$ of $\mathrm{OC}_{\text {total }}$ on average for the period in question (standard deviation of $12 \%$ ), strongly suggesting a major contribution of residential wood burning to organic aerosols during this period. Results obtained from the different source apportionment models (i.e., CMB, PMF and the Aethalometer model) are presented in the following sections.

\section{Chemical Mass Balance (CMB)}

\subsection{Methodology}

The Chemical Mass Balance (CMB) air quality model, which is one of the historical receptor based models, is widely used for air resources management purpose. It uses the chemical characteristics of the aerosol measured at both source and receptor to quantify source contributions to aerosol concentrations encountered at a receptor site. In this approach, the concentration of a selected chemical marker $i$ at receptor site $k, C_{i k}$, can be expressed as the following linear equation:

$C_{i k}=\sum_{j=1}^{m} f_{i j k} a_{i j} s_{j k}$

where $m$ is the total number of emission sources, $a_{i j}$ is the relative concentration of chemical species $i$ in fine OC emitted from source $j, \mathrm{~s}_{j k}$ is the increment to total OC concentration at receptor site $k$ originating from source $j$ and $f_{i j k}$ is the coefficient of fractionation that represents the modification of $a_{i j}$ during transport from source $j$ to receptor $k$.

The fractionation coefficient $f_{i j k}$ accounts for both selective loss of constituent $i$ and modification of primary OC concentrations originated from source $j$ due to atmospheric processes such as chemical aging or gas-particle partitioning related to the dilution of the emissions. In order to minimize the influence of such processes, key tracers considered as non volatile and stable in the atmosphere were used and their fractionation coefficients were set to 1 (Sheesley et al., 2007, Ke et al., 2007). These chemical markers are reported in Table 1. They include levoglucosan as a specific marker for biomass burning, elemental carbon (EC) and three hopanes (i.e., $17 \alpha(\mathrm{H}), 21 \beta(\mathrm{H})$-norhopane, $17 \alpha(\mathrm{H})$, $21 \beta(\mathrm{H})$-hopane and $22 \mathrm{~S}, 17 \alpha(\mathrm{H}), 21 \beta(\mathrm{H})$-homohopane) as key markers for vehicular emissions (Table 1). In addition, a series of C27-C31 n-alkanes were selected since this range demonstrates high odd-carbon preference that is specific to biogenic sources. Three PAH (benzo[e]pyrene, indeno[1,2,3cd]pyrene and benzo[ghi]perylene) were also included in order to constrain the different combustion sources. Although cholesterol and unsaturated acids are generally considered as good markers for meat cooking, high concentrations of cholesterol and unsaturated acids compounds derived from natural and from biomass burning emissions have recently been reported (Nolte et al., 2002; Lee et al., 2005). This observation is consistent with the fair correlation between cholesterol and levoglucosan observed in the present study $\left(R^{2}=0.66\right)$. The potential contribution of biogenic sources and biomass burning to these compounds is not well defined, and the use of cholesterol as markers for meat cooking would lead to an overestimation of the contribution of this specific source. Consequently, meat cooking was not considered in the present study. The set of linear combinations generated by Eq. (3) was resolved by means of the US-EPA-CMB8.2 software. In order to provide consistency to these results, statistical performance measures usually used in CMB modelling (i.e., R-square (target 0.8-1.0), Chi-square (target 0 4.0 ), t-test (target $>2$ ) and the absence of cluster sources) were investigated. Another quality control check was also established with a target value between 0.8 and 1.2 for the calculated-to-measured ratios of two key tracers, i.e., levoglucosan and EC (Table 2).

The source profiles considered in this study are drawn from the most recent and comprehensive reference studies. 


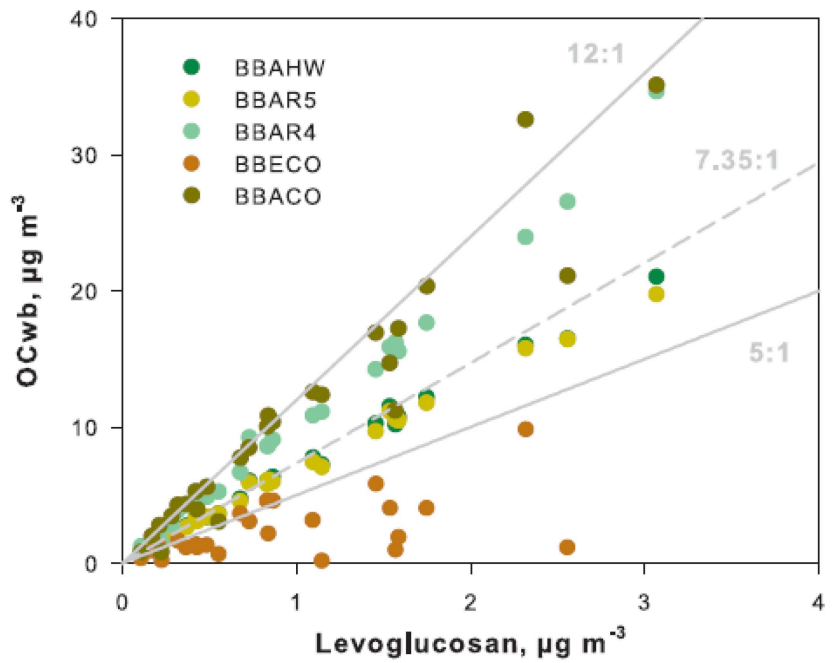

Fig. 3. Biomass burning organic carbon $\left(\mathrm{OC}_{\mathrm{wb}}\right)$ estimated using $\mathrm{CMB}$ modeling with the five selected biomass burning profiles as a function of levoglucosan. The dotted grey line represent the OCto-Levoglucosan ratio recommended by Puxbaum et al. (2007) for European background environments, while grey lines as used here as indicators.

They include vegetative detritus (Rogge et al., 1993a), natural gas combustion (Rogge et al., 1993a), and French vehicular emissions (El Haddad et al., 2009). Biomass burning emissions have received considerable attention in the last decade and many emission profiles have been established for a lot of wood species and combustion conditions (e.g. Puxbaum et al., 2007, and references therein). This variability makes the selection of the biomass burning profile a challenging issue. As no quantitative data regarding wood types used in the area under study are currently available, several wood combustion profiles were tested. These profiles are listed in Table 2. The BBAHW profile is based on Fine et al. (2002) and corresponds to an average calculated for hardwood combustion emissions. The BBAR4 and BBAR5 profiles are representative of biomass smoke aerosol in the south-eastern US (EPA region 4) and the Midwestern US (EPA region 5) respectively (Sheesley et al., 2007). Finally, BBACO and BBECO correspond to composite profiles calculated for the two most prevalent wood species in the French Alpine valleys (i.e., spruce and beech). These profiles are basically drawn from Fine et al. (2004) and Schmidl et al. (2008) respectively, and have been calculated according to the levoglucosan-to-mannosan ratios encountered during the field campaign. This ratio allows differentiating the two wood types as beech smoke are characterized by rather high levoglucosan-to-mannosan ratios $(\sim 15)$ whereas spruce smoke aerosol exhibits low levoglucosan-to-mannosan ratios ( 4) (Fine et al., 2004; Schmidl et al., 2008). A mean levoglucosan-to-mannosan ratio of 10.6 is obtained in this study, suggesting a contribution from beech smoke of $89 \%$ in the case of BBACO and of $94 \%$ in the case of BBECO. This result makes sense with the assumption of the prevalence of hardwood combustions in French cities.

Sensitivity tests were performed by running the model with each biomass burning profile in combination with the other source profiles. $\mathrm{OC}_{\mathrm{wb}}$ obtained considering the five different profiles is then plotted vs. levoglucosan concentrations (Fig. 3). Good correlations are obtained for the BBAHW, BBAR4, BBAR5 and BBACO profiles, suggesting that the levoglucosan-to-OC ratio dominates the biomass burning apportionment. Contrarily, the use of the BBECO profile does not show a clear linear dependence between the measured levoglucosan and the modelled $\mathrm{OC}_{\mathrm{wb}}$, and only $27 \%$ of the measured levoglucosan is explained by the model in this case. Moreover, the model greatly overestimates EC (Table 2). For these reasons, the BBECO profile can be excluded. It should be noted that such high discrepancies between the measurements and the outputs of the model primarily arise from the high EC-to-OC ratio in BBECO $(\sim 0.4)$, which was not originally obtained using the ECOC NIOSH thermo-optical method. Although this composite profile could be consider as the most representative because obtained from wood originated from the Alps, the later result underlines the overwhelming importance of analytical approaches for $\mathrm{EC} / \mathrm{OC}$ measurements for $\mathrm{CMB}$ applications. For BBAHW, BBAR4, BBAR5 and BBACO, levoglucosan and $\mathrm{EC}$ amounts are quantitatively explained by the model (see Table 2). Differences in the levoglucosan-to- $\mathrm{OC}_{\mathrm{wb}}$ ratios (Fig. 3) underlie the different slopes observed for the different profiles, and thereby the systematic biases between the different CMB solutions. On the one hand, the use of both the BBAR4 and BBACO profiles lead to physically unrealistic results with $\mathrm{OC}_{\mathrm{wb}}$ often exceeding the total OC (see Table 2). These two profiles can then be excluded. On the other hand, BBAHW and BBAR5 lead to physically realistic and very similar results (Fig. 3), both profiles attributing $\sim 68 \%$ of the organic carbon to biomass burning. These two latter profiles can be used almost indifferently in this study. This also seems to confirm the accuracy of the BBAHW profile for modelling wood burning emissions in European regions, as previously suggested by Puxbaum et al. (2007). Results presented below were obtained with the BBAHW profile.

It should be kept in mind that filter sampling artefacts and hypothesis made for assessing OC-to-OM ratios are sources of uncertainty for the CMB model (as well as for the Aethalometer model, presented in Sect. 6). From the comparison between off-line filter analyses and AMS measurements, sampling artefacts were estimated as representing about $10 \%$ of OC concentrations measured on HiVol filters. The relative uncertainties for OM contributions of a source $\mathrm{j}$ associated to a modification $\Delta(\mathrm{OC}-\text { to-OM })_{j}$ correspond to $\Delta(\mathrm{OC}-\text { to-OM })_{j} /(\mathrm{OC} \text {-to-OM })_{j}$ init. For example an increase of 0.1 of the OC-to-OM ratio for wood combustion (initial value 1.7) leads to an increase of $\sim 6 \%$ of the OM concentration attributed to biomass burning. 


\subsection{Results}

In order to compare the $\mathrm{CMB}$ results with those obtained using the AMS-PMF and Aethalometer models, OM mass related to the different sources was calculated applying an OC-to-OM conversion factor specific for each source, i.e., 1.7 for $\mathrm{OC}_{\mathrm{wb}}$ (based on Puxbaum et al., 2007, and references therein), 1.2 for vehicular emissions and natural gas combustion (based on Aiken et al., 2008; Mohr et al., 2009), and 2.0 for vegetative detritus (based on Kunit and Puxbaum, 1996; Matthias-Maser, 1998). The difference between the total OM, determined by applying an OC-to-OM conversion factor of 1.78 to total OC (see Sect. 3), and the apportioned OM attributed to primary sources represents the "other OM", often considered as a surrogate for SOA (Sheesley et al., 2007). According to these calculations, an OM-to-OC factor of 2.2 can be inferred for "other OM", which is consistent with an overwhelmingly secondary origin of this "other OM" fraction (Aiken et al., 2008).

Time series of the ambient OM apportioned by CMB are presented in Figure 4. Biomass burning appears as the dominant source of OM during the whole period, accounting on average for $67 \%$ of the total mass. Vehicular emissions contributed on average for $6 \%$ of the total OM. The contributions of vegetative detritus and natural gas combustion emissions were negligible during the field campaign (less than $2 \%$ ). The "other OM" fraction is $26 \%$ on average. A diurnal trend was observed with higher contributions of biomass burning to OM during the night ( $\sim 79 \%)$ than during the day $(\sim 58 \%)$. This result can be partly explained by an increase of residential heating during the night. In contrast, vehicular emissions and "other sources" daytime contributions were $8 \%$ and $31 \%$, respectively, whereas their nocturnal contributions were $6 \%$ and $15 \%$, respectively. These diurnal patterns are consistent with higher vehicular traffic and photochemical activity during the day.

The CMB analysis clearly suggests a predominance of POA with $\sim 75 \%$ of the total OM originating from wood burning, traffic and natural gas combustion aerosol. It is important to note that such source apportionment models are expected to overestimate primary emissions, due to experimental conditions of the source profile measurements (e.g. Donahue et al., 2009, and references therein). Indeed, organic markers-to-OC ratios are generally measured at higher concentrations (e.g. in laboratory studies or in tunnels) than that existing in the real atmosphere. Dilution of primary emissions in the atmosphere modifies the partitioning of primary organics between the gaseous and particulate phases. Dilution process leads to a loss of carbon from the POA and then to an overestimation of POA by CMB modelling. However this loss of carbon cannot be considered as a net loss since a fraction of the volatilized primary carbon reacts in the atmosphere and re-condenses in the particulate phase. Thus the question of POA overestimation by CMB mostly depends of the net carbon balance between losses

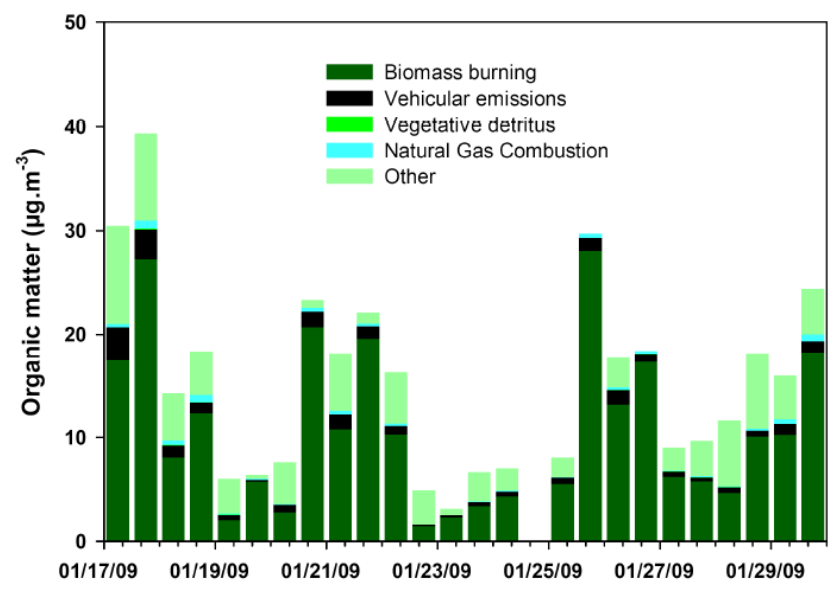

Fig. 4. Source contributions to ambient organic matter (OM) determined by the CMB modelling study (sampling intervals: 06:0018:00 and 18:00-06:00 UT).

by dilution and efficiency of the oxidation/condensation processes of the volatilized carbonaceous materials. Finally, as recently shown by Hoffmann et al. (2010), levoglucosan if present in deliquescent particles - may not be as stable as initially thought. Any levoglucosan degradation in the atmosphere might lead to an underestimation of wood burning $\mathrm{OM}$ by CMB.

\section{Positive Matrix Factorization (PMF)}

\subsection{Methodology}

Factor analysis has recently been shown to allow extracting information on OA sources from a linear decomposition of AMS organic mass spectra (Zhang et al., 2005) and considerable work has been performed on this issue over the last few years. In particular, a custom software tool, i.e., the PMF evaluation tool (PET) working in Igor Pro (Wavemetrics Inc.), has been developed to run and evaluate PMF2 outputs and related statistics. Results presented here were obtained using this methodology. A complete description of PMF2 and PET can be found in Paatero and Tapper (1994), Lanz et al. (2007) and Ulbrich et al. (2009). Briefly, time series of organic mass spectra, arranged as a matrix $(\mathbf{X})$, are factorized into a linear combination of smaller matrices following:

$x_{i, j}=\sum_{p} g_{i, p} f_{p, j}+e_{i, j}$

where $x_{i, j}$ correspond to the elements of matrix $\mathbf{X}, p$ represents the number of factors in the solution, $g_{i, p}$ and $f_{p, j}$ correspond to the element of matrices $\mathbf{G}$ and $\mathbf{F}$ representing respectively time series and mass spectra of each factor, and $e_{i, j}$ correspond to the elements of matrix $\mathbf{E}$ of residuals not fitted by the model for each data point. Within PMF2, no a 

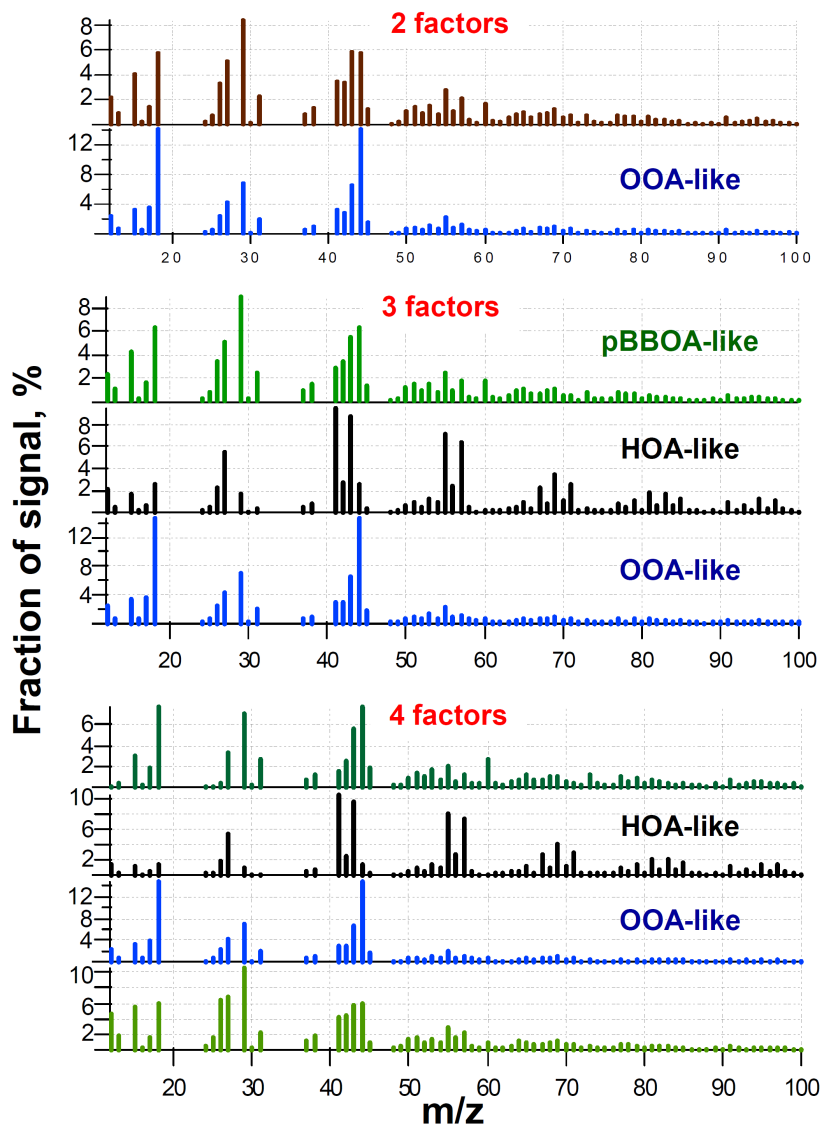

Fig. 5. Spectra of all PMF factors calculated by 2-, 3- and 4factorial PMF (PMF analysis for the 18-29 January period, with "FPEAK" $=-0.2$ and "seed" $=0$ ).

priori information is required about the values in $\mathbf{G}$ and $\mathbf{F}$, which are estimated based on an uncertainty-weighted leastsquare algorithm. This model makes use of a data matrix (of organic fragments) and an instrumental error matrix, both typically being obtained from the AMS-data-analysis Squirrel software. In this study, the data matrix is composed of 7698 data points (time series) of $246 \mathrm{~m} / \mathrm{z}$. These $246 \mathrm{~m} / \mathrm{z}$ correspond to the different $\mathrm{m} / \mathrm{z}$ 's comprised in the range 12 278 and with plausible significant organic fragments. The error matrix calculated in the Squirrel software was modified following the recommendations of Ulbrich et al. (2009) and references therein.

The first step of the PMF analysis is to determine the number of factors. An example of mass spectra obtained considering 2, 3 and 4 factors are presented in Fig. 5. For the 2factor solutions, only one factor could be related to a meaningful OA component, i.e., Oxygenated Organic Aerosols (OOA). This interpretation is based on comparisons with representative OOA spectra reported in previous studies and in the AMS Mass Spectral Database (http://cires.colorado.edu/ jimenez-group/AMSsd). The other factor is assessed to correspond to the mixing of the two factors that appeared in the 3-factor solutions, i.e., Hydrogenated Organic Aerosols (HOA) and primary Biomass Burning Organic Aerosols (pBBOA). This 3-factor-solution, which allows accounting for $\sim 99 \%$ of the total OA mass, is assumed to correspond to the "best number" of meaningful factors. Indeed, adding a fourth factor led to the splitting of the pBBOA factor (Fig. 5) and is thus assumed to be useless in this study. This splitting of the pBBOA factor within 4-factor solutions is hypothesized based on the co-variation of time series of the 2 "undefined" factors.

In order to explore the different linear transformations of the factor time series and mass spectra (usually referred as rotations), "FPEAK" parameters (see e.g. Lanz et al., 2007) ranging from -3.0 to 3.0 (with steps of 0.1 ) were then investigated. These calculations indicate two main groups of solutions, the first one corresponding to "FPEAK" values below -0.1 and the other one corresponding to "FPEAK" above -0.1 . The first group is preferred as it allows a much better separation of HOA and pBBOA time series than solutions obtained for "FPEAK" above -0.1. Mass spectra and time series of the different solutions were then compared (i) to reference mass spectra found in the AMS Mass Spectral Database (e.g. to those reported by Lanz et al., 2008, for wintertime conditions in Zurich, Switzerland), and (ii) to independent "external" tracer datasets of our study (i.e., concentrations of $\mathrm{NO}_{\mathrm{x}}$ for fossil fuel emissions, levoglucosan for wood burning emissions, and the sum $\left\{\mathrm{NO}_{3}^{-}+\mathrm{NH}_{4}^{+}+\mathrm{SO}_{4}^{2-}\right\}$ for secondary processes possibly leading to OOA). Results of these inter-comparisons suggest that the "best solution" is obtained for "FPEAK" $=-0.2$, for which $m / z$ 's and time series correlation coefficients are presented in Table 3. This solution also corresponds to minimum $\mathrm{Q} / \mathrm{Q}_{\exp }$ ratios, i.e., the total sum of the squares of the scaled residuals divided by the degrees of freedom of the fitted data, calculated for the different 3-factor solutions. Finally, in order to check that the retained solution does not correspond to a local minimum of the solution's space, different "seed" parameters (corresponding to pseudorandom starting-points of the PMF2 algorithm) ranging from 0 to 60 (with steps of 2) were tested. Based on these analyses, the 3 -factor solution corresponding to "FPEAK" $=-0.2$ and "seed" $=0$ is chosen for the dataset investigated here.

\subsection{Results}

The "best solution" described above indicates mean contributions of about $10 \%, 38 \%$ and $50 \%$ respectively for HOA, pBBOA and OOA during the period of study. It should be mentioned that, when considering the whole variety of the different 3-factor solutions (varying "FPEAK" between -3.0 and +3.0), HOA, pBBOA and OOA contributions were found to be comprised in the ranges $5-25 \%, 25-50 \%$ and 40\%-55\% respectively. Therefore, as observed worldwide (Jimenez et al., 2009), OOA was found to be the dominant fraction of OA, suggesting high contributions of secondary 


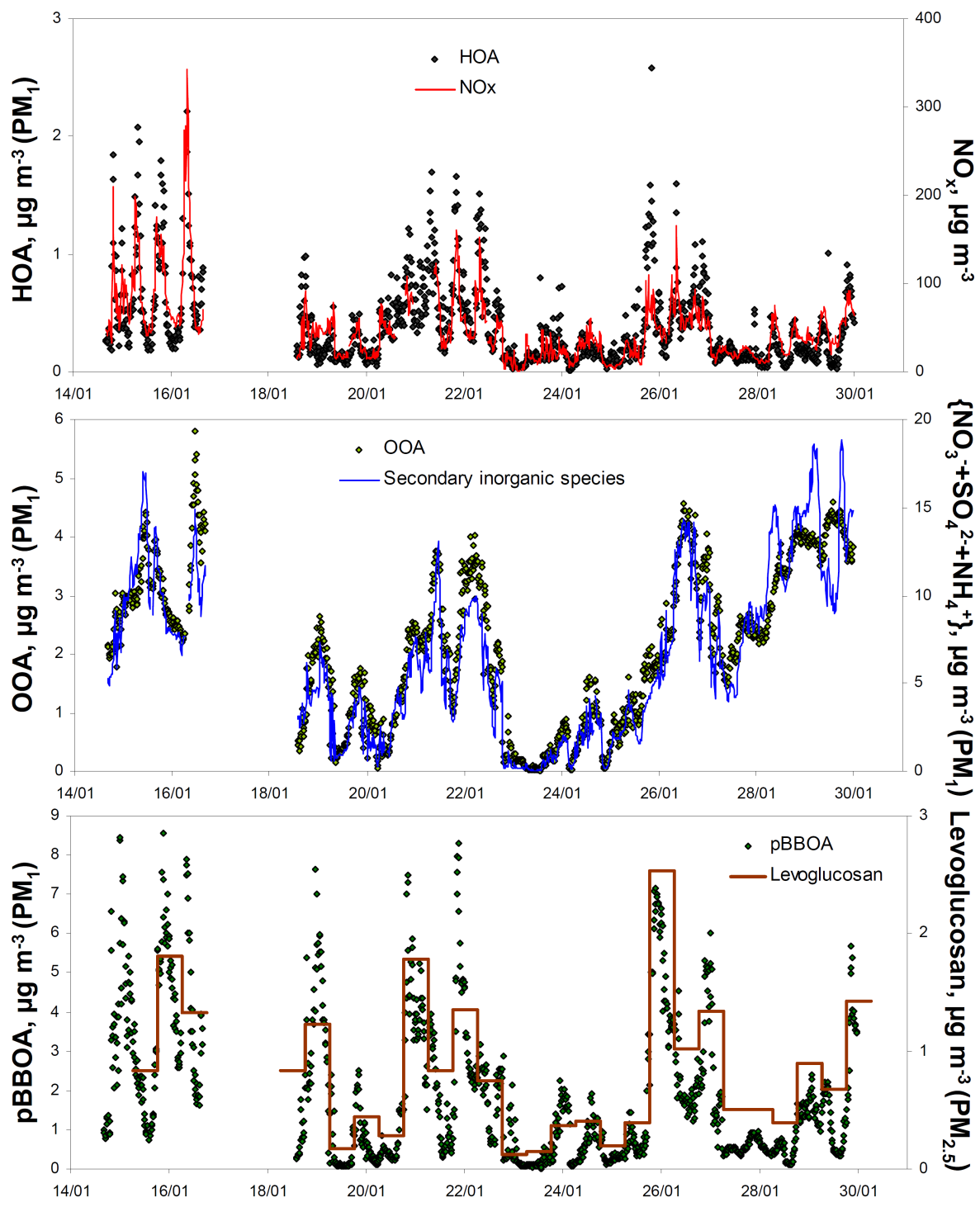

Fig. 6. Time series of each PMF factor (3-factorial PMF, "FPEAK" $=-0.2$ and "seed" $=0$ ) along with some of their corresponding tracers $\left(\mathrm{NO}_{\mathrm{x}}\right.$, secondary inorganic species and levoglucosan respectively for HOA, OOA and $\left.\mathrm{pBBOA}\right)$.

organic aerosols. The latter hypothesis is supported by the good correlation obtained between OOA and secondary inorganic aerosols (Table 3 and Fig. 6). However, it should be mentioned that such a satisfactory correlation may also be explained by the role of meteorological conditions in pollution level control over the two-week period investigated here. Moreover, as discussed below, OOA may actually comprise a non-negligible fraction of wood burning aerosols.

Among combustion sources, primary organics appeared to be largely dominated by wood burning emissions (pBBOA/HOA ratio of $\sim 5$ ). The separation between HOA and pBBOA is probably one of the most important issue when applying PMF analyses to AMS organic datasets (Lanz et al., 2008). In this study, high correlation coefficients are obtained between pBBOA and levoglucosan measurements, as well as between HOA and $\mathrm{NO}_{\mathrm{x}}$ (and $\mathrm{BC}$ ) loadings (Table 3 and Fig. 6). The pBBOA mass spectrum obtained in this study correlates well with mass spectra previously reported for this factor (e.g. $r^{2}=0.93$ when compared to that in Lanz et al., 2008). Interestingly, it also correlates well with the average of total organic mass spectra obtained in laboratory by Weimer et al. (2008) for 5 different types of wood burned under flaming conditions $\left(r^{2}=0.92\right)$. The latter study reported significant spectral discrepancies for OA emitted during the two main burning phases, i.e., flaming and smoldering. Typically, high amounts of mass fragments usually considered as wood burning markers (e.g. $m / z, 29,60$ and 73) were observed during the flaming phase, whereas mass spectra obtained during the smoldering phase were dominated by "oxygenated fragments" (e.g. $\mathrm{m} / \mathrm{z} 18$ and 44). In the present field 
Table 3. Mean contributions of each PMF factor during the period of study, and correlation coefficients obtained between their mass spectra and reference mass spectra as well as between their time series and tracer time series.

\begin{tabular}{lccc}
\hline & HOA & pBBOA & OOA \\
\hline Mean contributions to OA & $10 \%$ & $38 \%$ & $50 \%$ \\
\hline Correlations with reference mass spectra $\left(r^{2}\right)$ & & & \\
\hline HOA (Lanz et al., 2008) & $\mathbf{0 . 8 0}$ & 0.17 & 0.07 \\
Diesel bus exhaust (Canagartna et al., 2004) & $\mathbf{0 . 8 4}$ & 0.34 & 0.44 \\
pBBOA (Lanz et al., 2008) & 0.43 & $\mathbf{0 . 9 3}$ & 0.57 \\
Levoglucosan (Schneider et al., 2006) & 0.25 & $\mathbf{0 . 8 3}$ & 0.43 \\
Wood smoke (Weimer et al., 2008), flaming & 0.60 & $\mathbf{0 . 9 2}$ & 0.69 \\
Wood smoke (Weimer et al., 2008), smoldering & 0.20 & 0.52 & $\mathbf{0 . 9 5}$ \\
OOA (Lanz et al., 2008) & 0.30 & 0.71 & $\mathbf{0 . 9 9}$ \\
Fulvic acid (Alfarra et al., 2004) & 0.15 & 0.41 & $\mathbf{0 . 9 1}$ \\
\hline Correlations with "external" datasets $\left(r^{2}\right)$ & & & \\
\hline NO $_{x}$ (15-m averages) & $\mathbf{0 . 6 9}$ & 0.46 & 0.21 \\
BC (15-m averages) & $\mathbf{0 . 7 3}$ & 0.48 & 0.27 \\
Levoglucosan (12-h averages) & 0.45 & $\mathbf{0 . 8 9}$ & 0.19 \\
$\left\{\mathrm{NO}_{3}^{-}+\mathrm{NH}_{4}^{+}+\mathrm{SO}_{4}^{2-}\right\}$ (15-m averages) & 0.06 & 0.09 & $\mathbf{0 . 8 4}$ \\
\hline
\end{tabular}

study, pBBOA correlates much better with flaming-related organic spectra than with smoldering-related ones. However, wood burning aerosols investigated in the present study are expected to originate from both flaming and smoldering conditions. It might thus be hypothesized that the OOA fraction may actually contain some mass fragments related to primary (oxygenated) wood burning OA.

Mean diurnal variations of each OA components calculated using PMF2 are presented in Fig. 7a. Well-marked diurnal patterns could be observed for HOA and pBBOA. Maximum HOA loadings were obtained during traffic rush-hours, when they represented on average $\sim 12 \%$ of $\mathrm{OM}_{\mathrm{PM} 1}$ (as compared to $\sim 5 \%$ during nighttime). pBBOA loadings were found to peak between 21:00 and 02:00 ( $\sim 55 \%$ of $\left.\mathrm{OM}_{\mathrm{PM} 1}\right)$, with a second maximum during the morning. Compared to $\mathrm{HOA}$ and $\mathrm{pBBOA}$, a relatively flat diurnal cycle was obtained for OOA. However, concentrations of OOA increased on average by $\sim 20 \%$ during the afternoon, when OOA accounted for about $2 / 3$ of the total organic matter. This afternoon maximum is likely to be related to photochemical processes.

\section{The aethalometer model}

\subsection{Methodology}

The Aethalometer instrument was originally developed in order to quantify light absorption by black carbon (BC), which is considered as the predominant light absorbing aerosol species at visible wavelengths (Hansen et al., 1984). However, several studies recently pointed out that brown carbon (contained in some part of the particulate organic

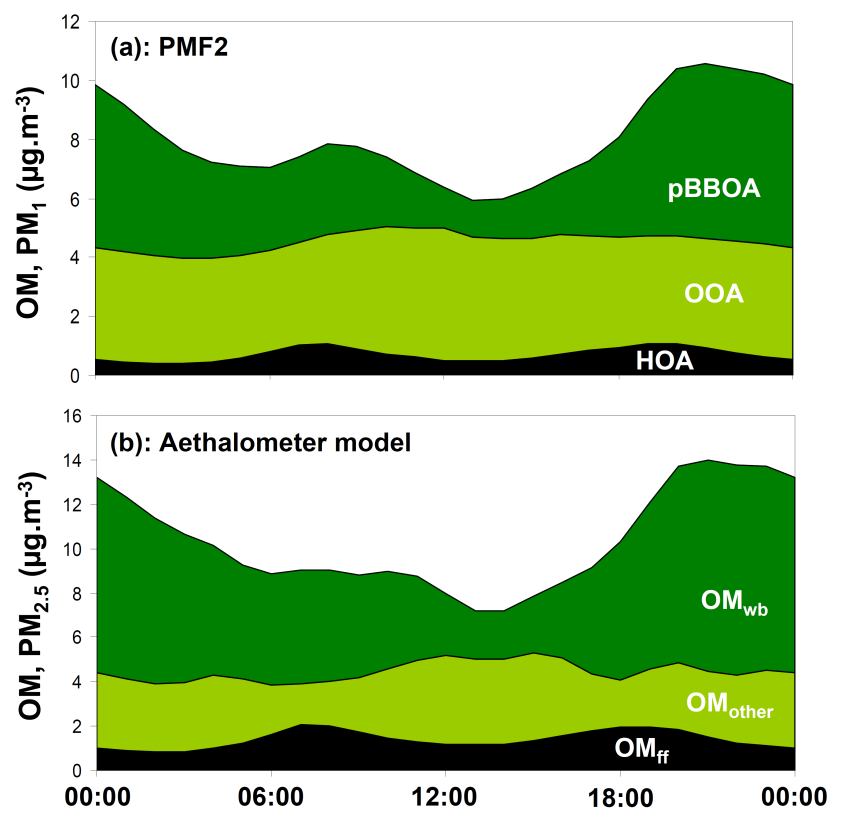

Fig. 7. Mean diurnal variations of each OA components obtained (a) using PMF2 as detailed in Sect. 5, and (b) using the Aethalometer model as detailed in Sect. 6.

matter), could significantly absorb light around 400-500 nm (e.g. Kirchstetter et al., 2004). Light absorption by aerosols is usually parameterized as proportional to $\lambda^{-\alpha}$, where $\lambda$ is the light wavelength and $\alpha$ represents the Ångstrom absorption exponent. While the spectral dependence of BC light absorption is low ( $\alpha \sim 1$; Bond and Bergstrom, 2006), brown carbon exhibits a much higher Ångstrom absorption exponent (up to 7; see e.g. Hoffer et al., 2006). Based on these differences in optical properties, a few studies recently used multiwavelength Aethalometers to detect the presence of biomass burning aerosols in ambient air (e.g. Jeong et al. , 2004; Sandradewi et al., 2008a; Yang et al., 2009). In a more quantitative way, using a multi-wavelength Aethalometer and carbon analyses, Sandradewi et al. (2008b, c) proposed two different methodologies allowing the quantification of wood burning carbonaceous aerosols. Based on the latter works we applied to our datasets a source apportionment model where total carbonaceous material $\left(\mathrm{CM}_{\mathrm{total}}\right)$ could be primarily considered as the sum of brown-carbon-containing carbonaceous material (i.e., $\mathrm{CM}_{\mathrm{wb}}$ here), non-brown-carbon-containing carbonaceous material originating from fossil fuel combustion $\left(\mathrm{CM}_{\mathrm{ff}}\right)$, and non-combustion $\mathrm{OA}\left(\mathrm{CM}_{\mathrm{other}}\right)$, as follows:

$$
\begin{aligned}
& \mathrm{CM}_{\text {total }}=\mathrm{CM}_{\mathrm{ff}}+\mathrm{CM}_{\mathrm{wb}}+\mathrm{CM}_{\text {other }} \\
& =\mathrm{C}_{1} \times b_{\mathrm{abs}, \mathrm{ff}, 950 \mathrm{~nm}}+\mathrm{C}_{2} \times b_{\mathrm{abs}, \mathrm{wb}, 470 \mathrm{~nm}}+\mathrm{C}_{3}
\end{aligned}
$$

where $b_{\text {abs,ff, } 950 \mathrm{~nm}}$ represents the absorption coefficient of $\mathrm{CM}_{\mathrm{ff}}$ at $950 \mathrm{~nm}, b_{\mathrm{abs}, \mathrm{wb}, 470 \mathrm{~nm}}$ represents the absorption coefficient of $\mathrm{CM}_{\mathrm{wb}}$ at $470 \mathrm{~nm}, \mathrm{C}_{1}$ and $\mathrm{C}_{2}$ relate the light absorption to the particulate mass of both sources, and $\mathrm{C}_{3}$ corresponds to the amount of non-combustion OA. It should be 
Table 4. Fitting of the Aethalometer model $\mathrm{C}_{2}$ and $\mathrm{C}_{3}$ parameters, using the two different carbonaceous aerosol datasets $\left(\right.$ see Eq. $5, \alpha_{\mathrm{ff}}=1.0$, $\alpha_{\mathrm{wb}}=2.0$, and $\mathrm{C}_{1}=2.6 \times 10^{5}$ ).

\begin{tabular}{lcc}
\hline & HiVol filter + Aethalometer datasets ${ }^{\mathrm{a}}$ & AMS + Aethalometer datasets $^{\mathrm{b}}$ \\
\hline $\mathrm{C}_{2}( \pm$ std. error $)$ & $8.1 \times 10^{5} \pm 0.3 \times 10^{5}$ & $6.7 \times 10^{5} \pm 0.8 \times 10^{4}$ \\
$\mathrm{C}_{3}$ ( \pm std. error $)$ & $3.1 \pm 0.5$ & $2.9 \pm 1.1$ \\
Correlation coef. $\left(r^{2}\right)$ & 0.96 & 0.84 \\
\hline
\end{tabular}

a 28 data points; ${ }^{\mathrm{b}} 1471$ data points.

noted that $\mathrm{CM}_{\mathrm{ff}}$ is assumed here to comprise traffic emissions as well as carbonaceous aerosols originating from fuel oil and natural gas combustion. Equation (5) can be solved when combined with Eqs. (6)-(9):

$$
\begin{aligned}
& \mathrm{CM}_{\text {total }}=\mathrm{BC}+\mathrm{OM} \\
& b_{\text {abs, } \lambda}=b_{\text {abs, ff, } \lambda}+b_{\text {abs, wb, } \lambda} \\
& \frac{b_{\mathrm{abs}, \mathrm{ff}, 470 \mathrm{~nm}}}{b_{\mathrm{abs}, \mathrm{ff}, 950 \mathrm{~nm}}}=\left(\frac{470}{950}\right)^{-\alpha_{\mathrm{ff}}} \\
& \frac{b_{\mathrm{abs}, \mathrm{wb}, 470 \mathrm{~nm}}}{b_{\mathrm{abs}, \mathrm{wb}, 950 \mathrm{~nm}}}=\left(\frac{470}{950}\right)^{-\alpha_{\mathrm{wb}}}
\end{aligned}
$$

where $\alpha_{\mathrm{ff}}$ and $\alpha_{\mathrm{wb}}$ represent the Angstrom absorption exponents of both combustion aerosol sources. Several studies reported consistent $\alpha_{\mathrm{ff}}$ values of about $1.0 \pm 0.1$ from various field and laboratory experiments (see e.g. Bond and Bergstrom, 2006). In this study, $\alpha_{\mathrm{ff}}$ is set to 1.0 , corresponding to the mean $\alpha$ value obtained for the $10 \%$ lowest $\mathrm{OM} / \mathrm{BC}$ ratios (15 min-averaged data obtained from AMS and Aethalometer measurements), i.e. corresponding to the periods when biomass burning emissions probably have the weakest influence on the total carbonaceous aerosol content. The absorption exponent of $\mathrm{CM}_{\mathrm{wb}}\left(\alpha_{\mathrm{wb}}\right)$ is very likely to be affected by the type of wood burned, by the combustion regime, and by the internal mixing with non-absorbing materials, leading to high discrepancies between the different values reported for $\alpha_{\mathrm{wb}}$ in previous studies (see e.g. Lewis et al., 2008). In the present study, $\alpha_{\mathrm{wb}}$ is set to 2.0, corresponding to a typical $\alpha_{\mathrm{wb}}$ value previously reported for wood burning aerosols (Kirchstetter et al., 2004; Day et al., 2006; Lewis et al. 2008). $C_{1}, C_{2}$ and $C_{3}$ may also strongly depend on the nature of the aerosols. However, for the same reasons than those exposed above, $\mathrm{C}_{1}$ (related to fossil fuel combustions) can be considered as less variable than $\mathrm{C}_{2}$ (notably influenced by the wood type and the combustion regime) and $\mathrm{C}_{3}$ (related to different aerosol sources). It thus appears reasonable to use a fixed $\mathrm{C}_{1}$ value in Eq. (5), and then calculate site-specific $\mathrm{C}_{2}$ and $\mathrm{C}_{3}$ constants. In the present study, $\mathrm{C}_{1}$ is set to 260000 , based on the work of Sandradewi et al. (2008b) and of Favez et al. (2009), both studies showing a very good agreement for this parameter.
Assuming these hypotheses, only $\mathrm{C}_{2}$ and $\mathrm{C}_{3}$ are unknown in Eq. (5), and a linear regression can be used to determine the mean values of these parameters during the period of study (Table 4). $\mathrm{C}_{2}$, corresponding to the slope of this linear regression, is then applied to the whole dataset to evaluate $\mathrm{CM}_{\mathrm{wb}}$. Finally, $\mathrm{CM}_{\mathrm{other}}$ is calculated for each data point as the difference between $\mathrm{CM}_{\mathrm{total}}$ and the sum $\left\{\mathrm{CM}_{\mathrm{ff}}+\mathrm{CM}_{\mathrm{wb}}\right\}$. In order to estimate the total uncertainties of the Aethalometer model outputs, sensitivity tests are performed here by varying $\alpha_{\mathrm{ff}}$ from 0.9 to $1.1, \alpha_{\mathrm{wb}}$ from 1.5 to 3.0 , and $\mathrm{C}_{1}$ from 200000 to 320000 . Results of these sensitivity tests are given in Table 5 .

Finally, in order to apportion the contribution of each component to elemental carbon $\left(\mathrm{BC}_{\mathrm{ff}}\right.$ and $\left.\mathrm{BC}_{\mathrm{wb}}\right)$ and to organic carbon $\left(\mathrm{OM}_{\mathrm{ff}}, \mathrm{OM}_{\mathrm{wb}}\right.$ and $\left.\mathrm{OM}_{\mathrm{other}}\right), \mathrm{BC}_{\mathrm{ff}}$ and $\mathrm{BC}_{\mathrm{wb}}$ are assumed to have equivalent mass absorption efficiencies, following:

$\mathrm{BC}_{\mathrm{ff}}=\mathrm{BC}_{\text {total }} \times \frac{b_{\mathrm{abs}, \mathrm{ff}, 950 \mathrm{~nm}}}{b_{\mathrm{abs}, \text { total, } 950 \mathrm{~nm}}}$

Based on Liousse et al. (1993), the latter hypothesis could lead to a $\mathrm{BC}_{\mathrm{wb}}$ overestimate of about $50 \%$ and an $\mathrm{OC}_{\mathrm{wb}}$ underestimate of about $10 \%$.

With the use of accurate absorption exponents, one of the trickiest issues of the Aethalometer model is probably the neglecting of brown-carbon-containing OA with other origins than primary biomass burning emissions. In particular, the presence of light absorbing SOA may not be excluded (Shapiro et al., 2009), possibly leading to an overestimation of primary wood burning OA using the Aethalometer model. Moreover, semi-volatile primary wood burning OA may rapidly evaporate after emissions, and later re-condense in the particulate phase after being (photo-)chemically processed (Grieshop et al., 2009a). Whether these compounds should be referred as SOA or as oxidized-POA is nowadays a subject of debate (Donahue et al., 2009). At this point, it is not possible to evaluate how much this phenomenon could affect the Aethalometer model. An overestimation of $\mathrm{C}_{2}$, due to a possible correlation of SOA (originating from the oxidation of gaseous compounds) and oxidized-POA, may also not be excluded. 
Table 5. Mean contributions ( \pm one standard deviation) of fossil fuel combustion, wood burning and non-combustion OA sources to carbonaceous aerosols obtained with the Aethalometer model and using the two different $\{\mathrm{EC} / \mathrm{BC}+\mathrm{OM}\}$ datasets (see Sect. 6.2). Lower and higher limits correspond to mean contributions obtained when ranging $\alpha_{\mathrm{ff}}$ from 0.9 to $1.1, \alpha_{\mathrm{wb}}$ from 1.5 to 3.0 , and $\mathrm{C}_{1}$ from $2.0 \times 10^{5}$ to $3.2 \times 10^{5}$ (see Sect. 6.1) .

\begin{tabular}{|c|c|c|c|c|c|c|c|c|c|}
\hline & \multicolumn{3}{|c|}{ Fossil fuel } & \multicolumn{3}{|c|}{ Wood burning } & \multicolumn{3}{|c|}{ Non-comb. OA sources } \\
\hline & $\begin{array}{l}\text { campaign } \\
\text { average }\end{array}$ & $\begin{array}{r}\text { lower } \\
\text { limit }\end{array}$ & $\begin{array}{l}\text { higher } \\
\text { limit }\end{array}$ & $\begin{array}{l}\text { campaign } \\
\text { average }\end{array}$ & $\begin{array}{r}\text { lower } \\
\text { limit }\end{array}$ & $\begin{array}{l}\text { higher } \\
\text { limit }\end{array}$ & $\begin{array}{l}\text { campaign } \\
\text { average }\end{array}$ & $\begin{array}{r}\text { lower } \\
\text { limit }\end{array}$ & $\begin{array}{r}\text { higher } \\
\text { limit }\end{array}$ \\
\hline \multicolumn{10}{|c|}{ HiVol filter + Aethalometer datasets ${ }^{\mathrm{a}}$} \\
\hline $\mathrm{EC}$ & $\mathbf{8 3} \pm 8 \%$ & $50 \%$ & $96 \%$ & $\mathbf{1 7} \pm 8 \%$ & $4 \%$ & $50 \%$ & & & \\
\hline $\mathrm{OM}$ & $13 \pm 5 \%$ & $6 \%$ & $18 \%$ & $\mathbf{6 0} \pm 21 \%$ & $43 \%$ & $74 \%$ & $\mathbf{2 8} \pm 19 \%$ & $20 \%$ & $39 \%$ \\
\hline \multicolumn{10}{|c|}{ AMS + Aethalometer datasets ${ }^{b}$} \\
\hline $\mathrm{BC}$ & $\mathbf{8 2} \pm 11 \%$ & $51 \%$ & $96 \%$ & $\mathbf{1 8} \pm 11 \%$ & $4 \%$ & $49 \%$ & & & \\
\hline $\mathrm{OM}$ & $\mathbf{1 4} \pm 27 \%$ & $3 \%$ & $25 \%$ & $\mathbf{5 6} \pm 40 \%$ & $38 \%$ & $68 \%$ & $\mathbf{3 0} \pm 34 \%$ & $26 \%$ & $37 \%$ \\
\hline
\end{tabular}

a 28 data points; ${ }^{\text {b }} 1471$ data points.

\subsection{Results}

As Aethalometer measurements were performed for the $\mathrm{PM}_{2.5}$ fraction, these calculations have been computed using $\mathrm{EC}$ and $\mathrm{OC}$ concentrations obtained from HiVol filter measurements (12-h sampling periods, total number of 28 data points), assuming an OC-to-OM conversion factor of 1.8 (see Sect. 3) and replacing BC by EC in Eqs. (6) and (10). Based on these calculations, fossil fuel, wood burning and non-combustion sources were found to account respectively for $13 \%, 60 \%$ and $28 \%$ of total OM on average for the period of study. Due to the number of approximations, these mean values were found to be associated with large confidence ranges $(6-18 \%, 43-74 \%$ and $20-39 \%$ respectively, see Table 5). These uncertainties are mostly related to the choice of absorption exponents. In particular, $\alpha_{\mathrm{ff}}$ reveals to be the most sensitive parameter for the determination of $\mathrm{OM}_{\mathrm{wb}}$ (and $\mathrm{OM}_{\mathrm{other}}$ ), with the contribution of wood burning emissions ranging from $48 \%$ to $69 \%$ (and the contribution of non-combustion aerosols ranging from $21 \%$ to $38 \%$ ) when varying $\alpha_{\mathrm{ff}}$ from 0.9 to 1.1 (for $\alpha_{\mathrm{wb}}=2.0$ and $\mathrm{C}_{1}=260000$ ). By contrast, the choice of $\alpha_{\mathrm{wb}}$ and $\mathrm{C}_{1}$ has only little impact $( \pm 3 \%)$ on the determination of $\mathrm{OM}_{\mathrm{wb}}$ and $\mathrm{OM}_{\mathrm{other}}$. However, $\alpha_{\mathrm{wb}}$ and $\mathrm{C}_{1}$ reveal to be the most sensitive parameters for the determination of $\mathrm{OM}_{\mathrm{ff}}$, with the contribution of fossil fuel emissions ranging from $8 \%$ to $15 \%$ when varying $\alpha_{\mathrm{wb}}$ from 1.5 to 3.0 (for $\alpha_{\mathrm{ff}}=1.0$ and $\mathrm{C}_{1}=260000$ ) and from $10 \%$ to $16 \%$ when varying $\mathrm{C}_{1}$ from 200000 to 320000 (for $\alpha_{\mathrm{ff}}=1.0$ and $\alpha_{\mathrm{wb}}=2.0$ ). Due to the hypothesis made in Eq. (10), even higher uncertainties were calculated for fossil fuel and wood burning contributions to EC (50-96\% and 4-50\% for fossil fuel and wood burning respectively).

Despite these high uncertainties, results obtained using the Aethalometer model clearly suggest that wood burning is the major OA contributor and, nevertheless, could poorly contribute to total EC, in good agreement with previous studies (e.g. Szidat et al., 2007). The accuracy of these results can be checked via comparisons with specific tracers of both sources (Fig. 8). Nitrogen oxide and dioxide $\left(\mathrm{NO}_{\mathrm{x}}\right)$, which are mainly related to fossil fuel emissions, correlate well with $\mathrm{OM}_{\mathrm{ff}}\left(r^{2}=0.93\right)$ and $\mathrm{EC}_{\mathrm{ff}}\left(r^{2}=0.94\right)$. For wood burning aerosols, satisfactory correlations are obtained for $\mathrm{OM}_{\mathrm{wb}}$ versus levoglucosan and for $\mathrm{EC}_{\mathrm{wb}}$ versus levoglu$\operatorname{cosan}\left(r^{2}=0.82\right.$ in both cases). Moreover, $\mathrm{OM}_{\mathrm{wb}}$ and $\mathrm{EC}_{\mathrm{wb}}$ are also found to correlate well with potassium concentrations measured on filter samples $\left(r^{2}=0.85\right.$ and 0.79 respectively), as well as with the WSOC contents also measured on HiVol filters $\left(r^{2}=0.94\right.$ and 0.88 respectively). It should also be noted that the mean $\mathrm{OC}_{\mathrm{wb}} /$ levoglucosan (i.e., about 6 , see Fig. 8), as well as mean OC/EC ratios (about 0.5 and 10 for fossil fuel and wood burning emissions respectively), calculated this way are in good agreement with those generally reported in source profile studies (e.g. Fine et al., 2002; ElHaddad et al., 2009). All of these results suggest that the Aethalometer model is able to accurately estimate fossil fuel and wood burning OA in this study.

In an attempt to investigate OA sources at a high time resolution (15 min averages, total number of 1471 data points) and to compare the Aethalometer model to the AMS-PMF approach, calculations presented in Sect. 6.1 have also been computed using $\mathrm{BC}$ and $\mathrm{OM}$ datasets obtained from real-time instruments, i.e., $\mathrm{BC}_{\mathrm{PM} 2.5}$ obtained from Aethalometer measurements (see Sect. 2.3) and $\mathrm{OM}_{\mathrm{PM} 2.5}$ calculated as $\mathrm{OM}_{\mathrm{PM} 1}$ concentrations measured by the AMS multiplied by 1.2 (corresponding to the mean $\mathrm{OC}_{\mathrm{PM} 2.5} / \mathrm{OC}_{\mathrm{PM} 1}$ ratio from the size distribution measurements using the LPI, see Sect. 3). Mean contributions of each source obtained from these calculations are very similar to those presented above (Table 5). Moreover, as shown in Fig. 9, $\mathrm{OM}_{\mathrm{wb}}$ obtained this way correlates well with the AMS $m / z 60$ mass fraction, which is widely 

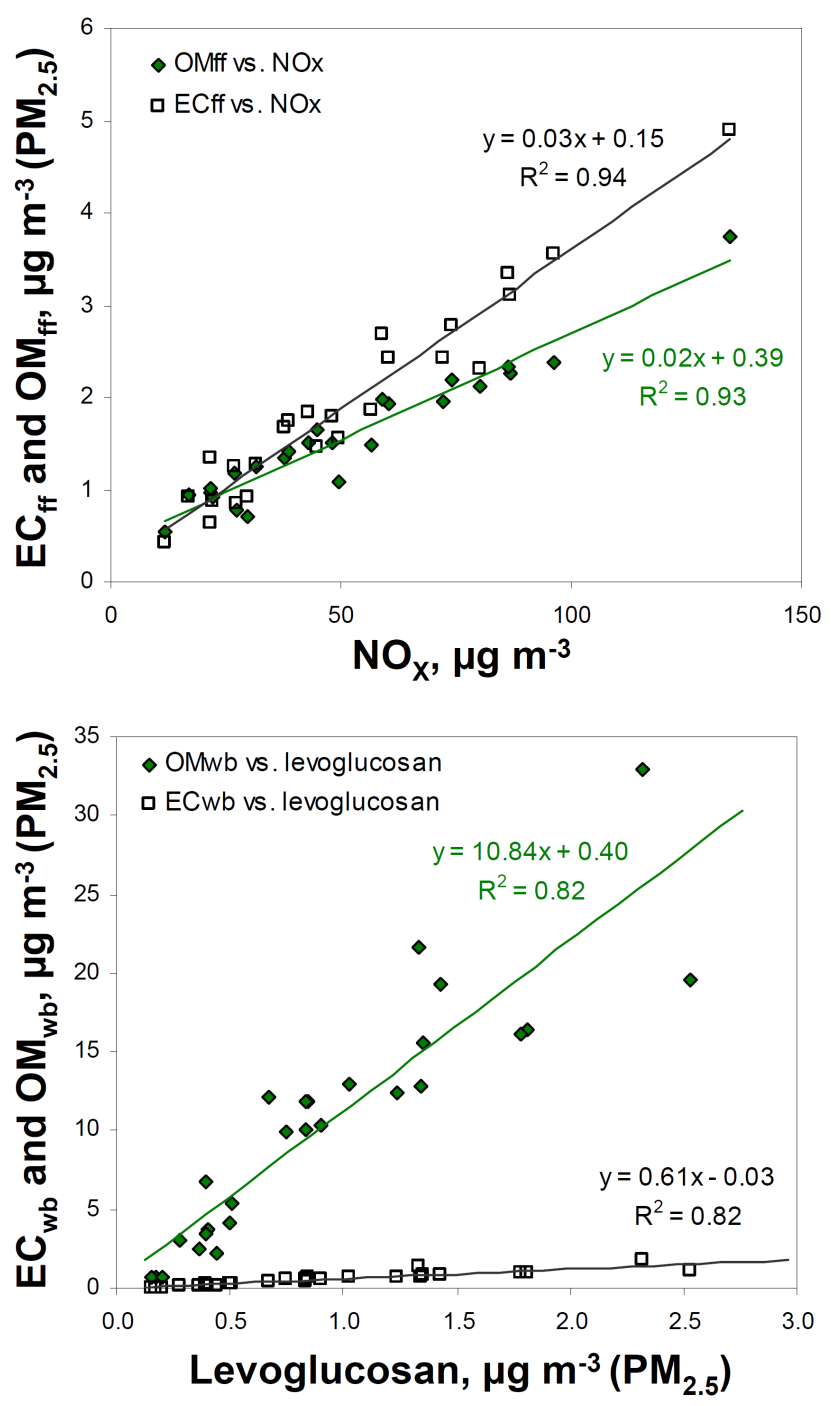

Fig. 8. Scatterplots of $\mathrm{EC}_{\mathrm{ff}}$ and $\mathrm{OM}_{\mathrm{ff}}$ as well as of $\mathrm{EC}_{\mathrm{wb}}$ and $\mathrm{OM}_{\mathrm{wb}}$, as calculated by the Aethalometer model, versus $\mathrm{NO}_{\mathrm{x}}$ and levoglucosan concentrations respectively.

used as a signature of biomass burning aerosols (e.g. Schneider et al., 2006). Such high correlation between $\mathrm{OM}_{\mathrm{wb}}$ and the $m / z 60$ signal has been reported previously by Sandradewi et al. (2008c).

The temporal variability of the contributions of each aerosol source is mainly related to diurnal variations, rather than to day-to-day variations. As presented in Fig. 7b, pronounced diurnal cycles were observed for each component of the organic fraction. Fossil fuel emissions were found to peak during traffic rush-hours, with mean OM contributions of about 23\% at 08:00 and 20\% at 19:00 LT (local time) (as compared to $\sim 8 \%$ during nighttime). Maximum contributions of wood burning aerosols were obtained between 20:00 and 02:00, when $\mathrm{OM}_{\mathrm{wb}}$ accounted for approximately $70 \%$ of the aerosol total organic matter content, whereas a

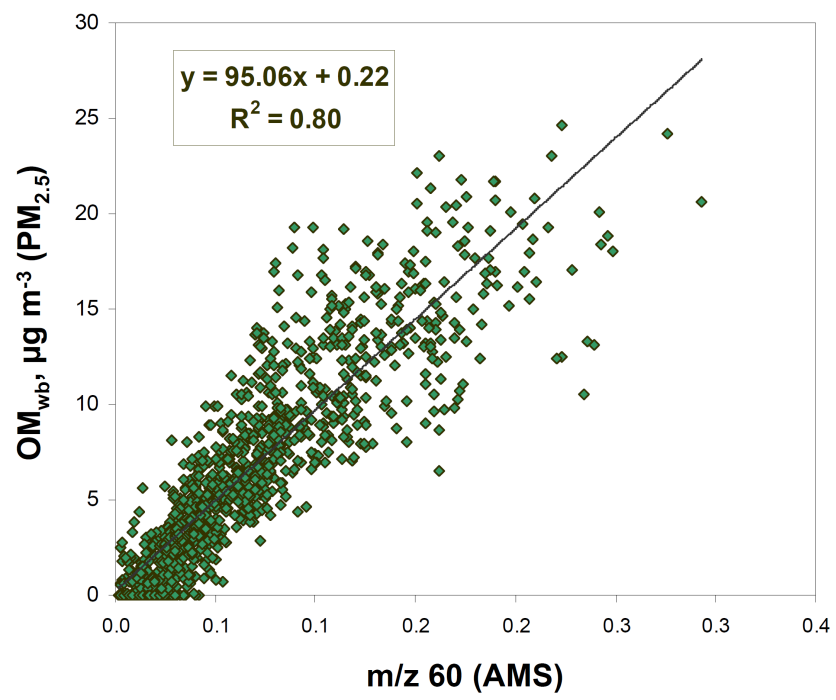

Fig. 9. Scatterplot of $\mathrm{OM}_{\mathrm{wb}}$, as calculated by the Aethalometer model, versus the $m / z, 60$ mass fraction measured by the AMS (15min averaged data).

second maximum was obtained after 07:00. This could be explained by an increase of residential wood burning during the evening and early morning. The mean contribution of other OA sources, i.e., non-combustion sources, ranged from $\sim 20 \%$ during traffic rush-hours to $\sim 50 \%$ in the middle of the day. This afternoon maximum may be related to the formation of SOA.

\section{Inter-comparison of the different source apportionment models}

This inter-comparison exercise is not straightforward, notably because the different models are not apportioning the same sources/factors and are related to different size fractions (i.e., $\mathrm{PM}_{2.5}$ for the $\mathrm{CMB}$ and Aethalometer models, $\mathrm{PM}_{1}$ for the AMS-PMF model). On a more conceptual view, AMS-PMF and Aethelometer models are linked to the whole chemical state of ambient OA while the CMB approach is based on a small fraction of the OA mass and apportions the total carbon mass whatever its chemical state (reacted or unreacted).

Concentrations of wood burning organic matter $\left(\mathrm{OM}_{\mathrm{wb}}\right)$ obtained from the CMB and the Aethalometer models $\left(\mathrm{PM}_{2.5}\right.$ fraction) are compared in Fig. 10a. A very good consistency is obtained for both datasets $\left(r^{2}=0.84\right)$, with the $\mathrm{CMB}$ model generally indicating higher (of about $10 \%$ on average) concentrations than the Aethalometer model. It is worth mentioning here that results of the Aethalometer model are pretty much the same (discrepancies below $5 \%$ ) whether the $\mathrm{CM}_{\text {total }}$ concentrations used in Eq. (6) are obtained using the EUSAAR2 or the NIOSH thermo-optical protocols. In order to compare the PMF and the Aethalometer models, $\mathrm{OM}_{\mathrm{wb}}$ 

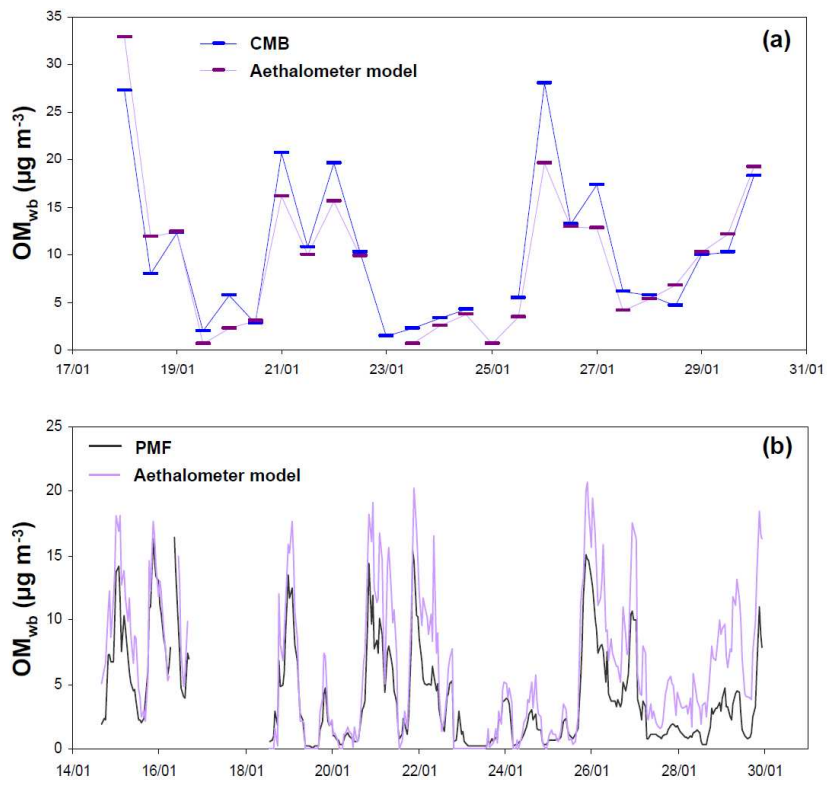

Fig. 10. Inter-comparisons of the time series of $\mathrm{OM}_{\mathrm{wb}}$ concentrations calculated by the different source apportionment models. (a) Outputs of the CMB and Aethalometer models (12h-averaged data, from 17 January 2009, 18:00 to 30 January 2009, 06:00). (b) Outputs of the AMS-PMF and Aethalometer models (15 minaveraged data, from 14 January 2009, 16:00 to 29 January 2009, 23:30).

modelled by the PMF for submicron aerosols were multiplied by a factor of 1.2 , corresponding to the mean $\mathrm{PM}_{2.5} / \mathrm{PM}_{1}$ ratio measured for organic aerosols (see Sect. 3). As presented in Fig. 10b, similar time series are obtained with both shorttime-scale models $\left(r^{2}=0.85\right)$, reinforcing the accuracy of our results. However, concentrations obtained using PMF are on average 30\% lower than that obtained using the Aethalometer model.

Based on these inter-comparisons, a good consistency could thus be observed between the temporal variations of $\mathrm{OM}_{\mathrm{wb}}$ datasets obtained from the different source apportionment models, but PMF indicated significantly lower concentrations than the CMB and the Aethalometer models. As presented in Fig. 11, during the period when the three modelling studies overlapped, mean contributions of wood burning organics to $\mathrm{OM}$ of $68 \%, 61 \%$ and $37 \%$ are obtained using the $\mathrm{CMB}$, the Aethalometer model and PMF respectively.

Lower $\mathrm{OM}_{\mathrm{wb}}$ concentrations (and contributions) obtained using the AMS-PMF model may be due to approximations made. In particular, it could be hypothesized that wood smoke contribute less importantly to $\mathrm{PM}_{1}$ as to $\mathrm{PM}_{2.5}$, so that the 1.2 value used to convert $\mathrm{PM}_{1}-\mathrm{OM}_{\mathrm{wb}}$ to $\mathrm{PM}_{2.5}-\mathrm{OM}_{\mathrm{wb}}$ may not be accurate. However, very similar volume size distributions are obtained for the 21:00-02:00 period (highly influenced by wood burning aerosols) and the 06:00-09:00 traffic rush-hours. Moreover, some previous studies reported that wood burning aerosols, and especially those generated

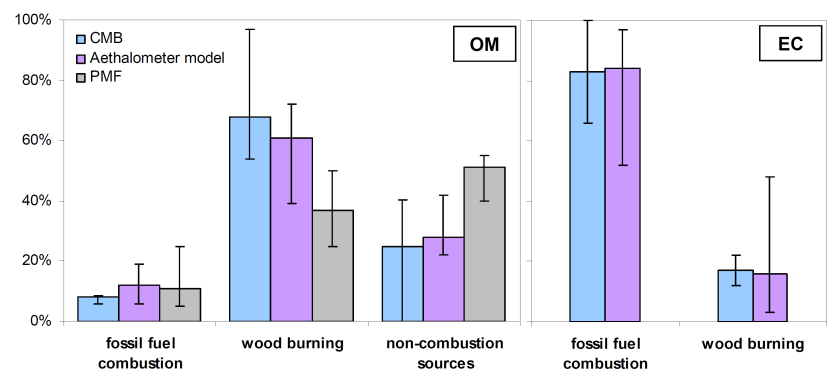

Fig. 11. Contributions of the three major sources (i.e., fossil fuel combustion, wood burning and non-combustion sources) to total fine organic matter (OM) and elemental carbon (EC) obtained from the different source apportionment models. The CMB and Aethalometer models were computed for $\mathrm{PM}_{2.5}$ carbonaceous aerosols, while PMF analyses were achieved on the organic data matrix obtained by the AMS for submicron aerosols. For PMF analyses, HOA, pBBOA and OOA were assumed here to correspond to fossil fuel combustion, wood burning and non-combustion sources respectively. Mean contribution presented were obtained for periods when CMB, PMF and Aethalometer modelling studies overlapped, i.e., from 17 January 2009, 18:00 to 29 January 2009, 18:00 (with the exceptions of 22 January 2009, 18:00 to 23 January 2009, 06:00 and of 24 January 2009, 18:00 to 25 January 2009, 06:00).

from the combustion of beech (the dominant tree species used for residential heating in Grenoble, see Sect. 4), display aerodynamic properties similar to those of diesel soot (Schneider et al., 2006), and display an accumulation mode centred roughly at the same diameter than traffic emissions (e.g. Weimer et al., 2009). It is also to note that, based on LPI measurement and assuming that the entire $\mathrm{PM}_{2.5}$ organic fraction not accurately measured by the AMS $(0.8-2.5 \mu \mathrm{m})$ is composed of wood burning OA (which is quite unrealistic), the mean $\mathrm{OM}_{\mathrm{wb}}$ contribution obtained using PMF would not be above $55 \%$.

Besides elevated uncertainties related to each source apportionment model, discrepancies between quantitative results of these models may also be related to (i) the overestimation of primary OA using the CMB model, due to modifications of the marker-to-OC ratios from sources to receptor site (see Sect. 4), (ii) the overestimation of primary OA using the Aethalometer model, due to the possible contribution of anthropogenic SOA within $\mathrm{OM}_{\mathrm{wb}}$ (see Sect. 6), and (iii) the underestimation of primary OA using the PMF model, due to the probable accounting of (oxygenated) mass fragments from primary wood burning OA within the OOA factor (see Sect. 5). It may also be hypothesized that the aging of primary wood burning OA could lead to mass fragments accounted for by the OOA fraction. The latter hypothesis could partly explain the presence of higher $m / z 60$ mass fraction in OOA mass spectra reported for winter experiments (e.g. Lanz et al., 2008, and the present study) than in mass spectra reported for summer experiments (e.g. Zhang et al., 2005; Lanz et al., 2007). 


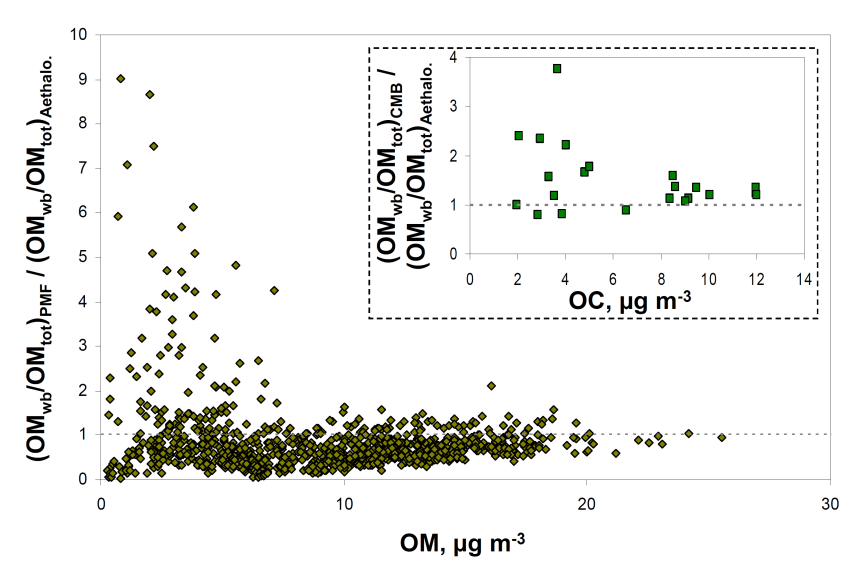

Fig. 12. Ratios of $\mathrm{OM}_{\mathrm{wb}}$ contributions obtained using the Aethalometer model and PMF (and using the Aethalometer and CMB models) as a function of OM (OC) mass loadings.

Further, it is very likely that lower $\mathrm{OM}_{\mathrm{wb}}$ contributions obtained from the AMS-PMF model are partly related to the presence of Oxidized Primary Organic Aerosols (OPOA), resulting from the rapid oxidation in the gas phase of lowvolatile and/or semi-volatile organics that were present in the particulate phase during emission (Donahue et al., 2009; Grieshop et al., 2009a). Such wood-smoke-related OPOA display mass spectra very similar to that of the OOA factor (Grieshop et al., 2009b), and can thus lead to mass fragments interpreted in this OOA fraction. Conversely, light-absorbing OPOA, if any, could be accounted as $\mathrm{OM}_{\mathrm{wb}}$ within the Aethalometer model; and the presence of OPOA in the particulate phase could partly compensate the above-described POA overestimation by CMB.

Another interesting result arising from this intercomparison exercise is that the Aethalometer model is likely to underestimate the contribution of biomass burning OA in relatively clean atmospheres. Indeed, compared to other models, lower $\mathrm{OM}_{\mathrm{wb}}$ contributions are obtained with the Aethalometer model when OM loadings are relatively low (i.e., below $\sim 5 \mu \mathrm{g} \mathrm{m}^{-3}$ ), as shown in Fig. 12. This has to be related to the loss of semi-volatile light absorbing organics from the Aethalometer filter tape during long-time sampling/measurement on a given "spot". Such an artefact has already been observed in laboratory at Magee Scientific, investigating the loss from the filter tape, and under clean air conditions, of previously sampled wood burning OA (T. Hansen, personal communication, 2009).

Finally, it is to note that a relatively good consistency was observed for the apportionment of fossil fuel OA using the three different models, as well as for the source apportionment of EC concentrations (Fig. 11). Discrepancies between the contributions of other organic sources (than fossil fuel and biomass burning emissions) obtained by the three models may be mainly related to considerations discussed above.

\section{Conclusions}

In the present study, we investigated the chemical composition of the fine aerosol fractions $\left(\mathrm{PM}_{1}\right.$ and $\left.\mathrm{PM}_{2.5}\right)$ in an Alpine city (Grenoble, France) during the winter season. Carbonaceous aerosols $(\mathrm{BC}+\mathrm{OM})$ were found to account for about $65 \%$ of these fine aerosol fractions. Three different source apportionment models (i.e., the CMB, AMS-PMF and Aethalometer models) were used to determine the influence of wood burning emissions on high organic aerosol loadings. A very good consistency was observed between $\mathrm{OM}_{\mathrm{wb}}$ temporal variations obtained from each model. However, $\mathrm{OM}_{\mathrm{wb}}$ concentrations (and contributions) estimated using PMF were on average $30 \%$ lower than that calculated using the Aethalometer model, and more than $40 \%$ lower than that calculated using CMB. Besides uncertainties related to each source apportionment model, these discrepancies are assessed to be mainly due to differences in the conceptual hypotheses made for each model. In other words, these discrepancies raise the issue whether source apportionment studies should estimate the remaining unreacted constituents of primary emissions or the amount of particulate matter that are related to unreacted and to processed primary emissions. In the first case, $\mathrm{CMB}$ and Aethalometer modelling studies certainly overestimate POA contributions, due to the loss of SVOM during transport and to the probable accounting by the Aethalometer model of anthropogenic SOA within $\mathrm{OM}_{\mathrm{wb}}$. In the second case, AMS-PMF models probably underestimate the impacts of wood burning primary emissions, notably due to the accounting of wood-smoke related OPOA within the OOA factor.

It is also worth mentioning here that the recentlydeveloped Aethalometer model seems to be able to provide satisfactory estimates of the contribution of wood burning emissions to carbonaceous aerosols, even in environments where secondary aerosols cannot be neglected. However, it also appears that this model certainly underestimate $\mathrm{OM}_{\mathrm{wb}}$ concentrations in relatively clean atmospheres. Further works are moreover still needed in order to investigate the ability of this model to account for wood-smoke-related OPOA and/or SOA.

Finally, based on converging results of this intercomparison exercise, wood burning OA could reasonably be considered as representing at least $50 \%$ of $\mathrm{OM}_{\mathrm{PM} 2.5}$ in Grenoble during the period of study. These results are somehow higher than contributions previously reported for other large European urban centres (see introduction). Moreover, preliminary CMB modelling studies performed on the whole $\mathrm{PM}_{2.5}$ fraction (including EC, sulfate, nitrate and ammonium) indicate that biomass burning remains the major source of $\mathrm{PM}_{2.5}$ (data not shown). Such high biomass burning contributions have to be related to the importance of residential wood burning emissions in France, which is the first wood consumer country in Europe (with about 7.5 tonnes of oil equivalent per year). Furthermore, the topography of the 
Grenoble area prevents any efficient wind-driven dispersion of atmospheric pollutants, and important pollution episodes are often observed there. Public policies dedicated to the reduction of residential wood burning emissions might thus allow a considerable improvement of the air quality during the winter season in this urban centre, as well as in other French/European cities.

Acknowledgements. This work was supported by the Agence gouvernementale De l'Environnement et de la Maitrise de l'Energie (ADEME) under the PRIMEQUAL2 grant no. 0001135 (FORMES program), the Centre National de la Recherche Scientifique (CNRS) and the Institut National des Sciences de l'Univers (INSU). O. F. gratefully acknowledges Ingrid M. Ulbrich (CIRES/University of Colorado) and Valentin Lanz (EMPA, Switzerland) for shared discussions about PMF2.

Edited by: A. S. H. Prevot

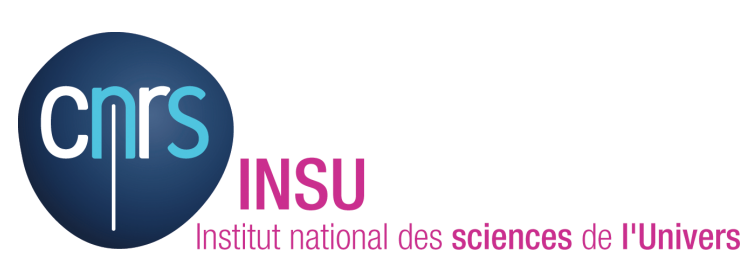

The publication of this article is financed by CNRS-INSU.

\section{References}

Aiken, A. C., DeCarlo, P. F., Kroll, J. H., et al.: O/C and OM/OC Ratios of Primary, Secondary, and Ambient Organic Aerosols with High-Resolution Time-of-Flight Aerosol Mass Spectrometry, Environ. Sci. Technol., 12, 4478-4485, 2008.

Alfarra, M. R.: Insights into atmospheric organic aerosols using an aerosol mass spectrometer, $\mathrm{PhD}$ Thesis, University of Manchester, 2004.

Allan, J. D., Delia, A. E., Coe, H., et al.: A generalised method for the extraction of chemically resolved mass spectra from aerodyne aerosol mass spectrometer data, J. Aerosol Sci., 35, 909-922, 2004.

Andreae, M. O. and Gelencsér, A.: Black carbon or brown carbon? The nature of light-absorbing carbonaceous aerosols, Atmos. Chem. Phys., 6, 3131-3148, doi:10.5194/acp-6-3131-2006, 2006.

Aymoz, G., Jaffrezo, J. L., Chapuis, D., Cozic, J., and Maenhaut, W.: Seasonal variation of $\mathrm{PM}_{10}$ main constituents in two valleys of the French Alps, I: EC/OC fractions, Atmos. Chem. Phys., 7, 661-675, doi:10.5194/acp-7-661-2007, 2007.

Arnott, W. P., Hamasha, K., Moosmüller, H., Sheridan, P. J., and Ogren, J. A.: Towards aerosol light-absorption measurements with a 7-wavelength aethatolometer: evaluation with a photoacoustic instrument and a 3-wavelength nephelometer, Aerosol Sci. Tech., 39, 17-29, 2005.

Birch, M. E. and Cary, R. A.: Elemental carbon-based method for monitoring occupational exposures to particulate diesel exhaust, Aerosol Sci. Tech., 25, 221-241, 1996.
Bond, T. C. and Bergstrom, R. W.: Light absorption by carbonaceous particles: an investigative review, Aerosol Sci. Tech., 40, 27-67, 2006.

Canagaratna, M. R., Jayne, J. T., Ghertner, D. A., et al.: Chase studies from in-use New-York city vehicles, Aerosol Sci. Tech., 38, 555-573, 2004.

Caseiro, A., Bauer, H., Schmidl, C., Pio, C. A., and Puxbaum, H.: Wood burning impact on $\mathrm{PM}_{10}$ in three Austrian regions, Atmos. Environ., 43, 2186-2195, 2009.

Cavalli, F., Viana, M., Yttri, K. E., Genberg, J., and Putaud, J.P.: Toward a standardised thermal-optical protocol for measuring atmospheric organic and elemental carbon: the EUSAAR protocol, Atmos. Meas. Tech., 3, 79-89, doi:10.5194/amt-3-79-2010, 2010.

Drewnick, F., Hings, S. S., DeCarlo, P., et al.: A new time-of-flight aerosol mass spectrometer (TOF-AMS) - Instrument description and first field deployment, Aerosol Sci. Tech., 39, 637-658, 2005.

Donahue, N. M., Robinson, A. L., Stanier, C. O., and Pandis, S. N.: Coupled partitioning, dilution, and chemical aging of semivolatile organics, Environ. Sci. Technol., 8, 2635-2643, 2006.

Donahue, N. M., Robinson, A. L., and Pandis, S. N.: Atmospheric organic particulate matter: From smoke to secondary organic aerosol, Atmos. Environ., 43, 94-106, 2009.

El Haddad, I., Marchand, N., Dron, J., et al.: Comprehensive primary particulate organic characterization of vehicular exhaust emissions in France, Atmos. Environ., 43, 6190-6198, 2009.

Favez, O., Cachier, H., Sciare, J., Sarda-Estève, R., and Martinon, L.: Evidence for a significant contribution of wood burning aerosols to $\mathrm{PM}_{2.5}$ during the winter season in Paris, France, Atmos. Environ., 43, 3640-3644, 2009.

Fine, P. M., Cass, G. R., and Simoneit, B. R. T.: Chemical characterization of fine particle emissions from the fireplace combustion of woods grown in the Southern United States, Environ. Sci. Technol., 36, 1442-1451, 2002.

Fine, P. M., Cass, G. R., and Simoneit, B. R. T.: Chemical characterization of fine particle emissions from the fireplace combustion of woods grown in the Midwestern and Western United States, Environ. Eng. Sci., 21, 387-409, 2004.

Grieshop, A. P., Logue, J. M., Donahue, N. M., and Robinson, A. L.: Laboratory investigation of photochemical oxidation of organic aerosol from wood fires 1: measurement and simulation of organic aerosol evolution, Atmos. Chem. Phys., 9, 1263-1277, doi:10.5194/acp-9-1263-2009, 2009a.

Grieshop, A. P., Donahue, N. M., and Robinson, A. L.: Laboratory investigation of photochemical oxidation of organic aerosol from wood fires 2: analysis of aerosol mass spectrometer data, Atmos. Chem. Phys., 9, 2227-2240, doi:10.5194/acp-9-2227-2009, 2009b.

Hansen, A. D. A., Rosen, H., and Novakov, T.: The Aethalometer An instrument for the real-time measurement of optical absorption by aerosol particles, Sci. Total Environ., 36, 191-196, 1984.

Hoffer, A., Gelencsér, A., Guyon, P., Kiss, G., Schmid, O., Frank, G. P., Artaxo, P., and Andreae, M. O.: Optical properties of humic-like substances (HULIS) in biomass-burning aerosols, Atmos. Chem. Phys., 6, 3563-3570, doi:10.5194/acp-6-3563-2006, 2006. 
Hoffmann, D., Tilgner, A., Iinuma, Y., and Herrmann, H.: Atmospheric stability of levoglucosan: a detailed laboratory and modeling study, Environ. Scechnol., 44, 694-699, 2010.

Jaffrezo, J. L., Calas, N., and Boucher, M.: Carboxylic acids measurements with ionic chromatography, Atmos. Environ., 32, 2705-2708, 1998.

Jaffrezo, J.-L., Aymoz, G., Delaval, C., and Cozic, J.: Seasonal variations of the water soluble organic carbon mass fraction of aerosol in two valleys of the French Alps, Atmos. Chem. Phys., 5, 2809-2821, doi:10.5194/acp-5-2809-2005, 2005.

Jeong, C.-H., Hopke, P. K., Kim, E., and Lee, D.-W.: The comparison between thermal-optical transmittance elemental carbon and Aethalometer black carbon measured at multiple monitoring sites, Atmos. Environ., 38, 5193-5204, 2004.

Jeong, C.-H., Evans, G. J., Dann, T., et al.: Influence of biomass burning on wintertime fine particulate matter: Source contribution at a valley site in rural Bristish Columbia, Atmos. Environ., 42, 3684-3699, 2008.

Jimenez, J. L., Canagaratna, M. R., Donahue, N. M., et al.: Evolution of organic aerosols in the atmosphere, Science, 11, 15251529, 2009.

Ke, L., Ding, X., Tanner, R. L., Schauer, J. J., and Zheng, M.: Source contributions to carbonaceous aerosols in the Tennessee Valley Region, Atmos. Environ., 39, 8898-8923, 2007.

Kingham, S., Durand, M., Harrison, J., Cavanagh, J., and Epton, M.: Temporal variations in particulate exposure to wood smoke in a residential school environment, Atmos. Environ., 42, 46194631, 2008.

Kirchstetter, T. W., Novakok, T., and Hobbs, P. V.: Evidence that the spectral dependence of light absorption by aerosols is affected by organic carbon, J. Geophys. Res., 109, D21208, doi:10.1029/2004JD004999, 2004.

Kunit, M. and Puxbaum, H.: Enzymatic determination of the cellulose content of atmospheric aerosols, Atmos. Environ., 30, 12331236, 1996.

Lack, D., Cappa, C., Covert, D., et al.: Bias in filter-based aerosol light absorption measurements due to organic aerosol loading: evidence from ambient measurements, Aerosol Sci. Tech., 42, 1033-1041, 2008.

Lanz, V. A., Alfarra, M. R., Baltensperger, U., Buchmann, B., Hueglin, C., and Prévôt, A. S. H.: Source apportionment of submicron organic aerosols at an urban site by factor analytical modelling of aerosol mass spectra, Atmos. Chem. Phys., 7, 1503-1522, doi:10.5194/acp-7-1503-2007, 2007.

Lanz, V. A., Alfarra, M. R., Baltensperger, U., et al.: Source attribution of submicron organic aerosols during wintertime inversions by advanced factor analysis of aerosol mass spectra, Environ. Sci. Technol., 42, 214-220, 2008.

Lanz, V. A., Prévôt, A. S. H., Alfarra, M. R., Mohr, C., DeCarlo, P. F., Weimer, S., Gianini, M. F. D., Hueglin, C., Schneider, J., Favez, O., D’Anna, B., George, C., and Baltensperger, U.: Characterization of aerosol chemical composition by aerosol mass spectrometry in Central Europe: an overview, Atmos. Chem. Phys. Discuss., 9, 24985-25021, doi:10.5194/acpd-924985-2009, 2009.
Lee, S., Baumann, K., Schauer, J. J., Sheesley, R. J., Naeher, L. P., Meinardi, S., Blake, D. R., Edgerton, E. S., Russell, A. G., and Clements, M.: Gaseous and Particulate Emissions from Prescribed Burning in Georgia, Environ. Sci. Technol., 23, 9049 9056, 2005.

Lewis, K., Arnott, W. P., Moosmüller, H., and Wold, C. E.: Strong spectral variation of biomass smoke light absorption and single scattering albedo observed with a novel dual-wavelength photoacoustic instrument, J. Geophys. Res., 113, D16203, doi:10.1029/2007JD009699, 2008.

Lewtas, J.: Air pollution combustion emissions: characterization of causative agents and mechanisms associated with cancer, reproductive, and cardiovascular effects, Mutat. Res. - Rev. Mutat., 636, 95-133, 2007.

Liousse, C., Cachier, H., and Jennings, S. G.: Optical and thermal measurements of black carbon aerosol content in different environments - variation of the specific attenuation cross section, sigma $(\sigma)$, Atmos. Environ., 27A, 1203-1211, 1993.

Matthew, B. M., Middlebrook, A. M., and Onasch, T. B.: Collection efficiencies in an aerodyne aerosol mass spectrometer as a function of particle phase for laboratory generated aerosols, Aerosol Sci. Tech., 42, 884-898, 2008.

Mattias-Maser, S.: Primary biological aerosol particles: their significance, sources, sampling methods and size distribution in the atmosphere, in: Atmospheric Particles, edited by: Harrison, R. M. and Van Grieken, R., Wiley, West Sussex, UK, 349-368, 1998.

Mohr, C., Huffman, J. A., Cubison, M. J., Aiken, A. C., Docherty, K. S., Kimmel, J. R., Ulbrich, I. M., Hannigan, M., and Jimenez, J. L.: Characterization of Primary Organic Aerosol Emissions from Meat Cooking, Trash Burning, and Motor Vehicles with High-Resolution Aerosol Mass Spectrometry and Comparison with Ambient and Chamber Observations, Environ. Sci. Technol., 7, 2443-2449, 2009.

NIOSH: Elemental Carbon (Diesel exhaust), in: NIOSH Manual of Analytical Methods, National Institute of Occupational Safety and Health, Cincinnati, OH, 1996.

Nolte, C. G., Schauer, J. J., Cass, G. R., and Simoneit, B. R. T.: Trimethylsilyl Derivatives of Organic Compounds in Source Samples and in Atmospheric Fine Particulate Matter, Environ. Sci. Technol., 20, 4273-4281, 2002.

Paatero, P. and Tapper, U.: Positive matrix factorization: a nonnegative factor model with optimal utilization of error estimates of data values, Environmetrics, 5, 111-126, 1994.

Park, K., Kittelson, D. B., Zachariah, M. R., and McMurry, P. H.: Measurement of inherent material density of nanoparticle agglomerates, J. Nanopart. Res., 6, 267-272, 2004.

Piot, C., Pissot, N., Mettra, B., El Haddad, I., Marchand, N., Jaffrezo, J.-L., and Besombes, J.-L.: Determination of levoglucosan and its isomers by High Performance Liquid Chromatography Electrospray Ionization tandem Mass Spectrometry and its application to atmospheric and soils samles, in perparation, 2010.

Puxbaum, H., Caseiro, A., Sánchez-Ochoa, A., Kasper-Giebl, A., Claeys, M., Gelencsér, A., Legrand, M., Preunkert, S., and Pio, C.: Levoglucosan levels at background sites in Europe for assessing the impact of biomass combustion on the aerosol European background, J. Geophys. Res., 112, D23S05, doi:10.1029/2006JD008114, 2007. 
Ricard, V., Jaffrezo, J. L., Kerminen, V. M., Hillamo, R. E., Sillanpää, M., Ruellan, S., Liousse, C., and Cachier, H.: Two years of continuous aerosol measurements in northern Finland, J. Geophys. Res., 107, 409, doi:10.1019/2001JD000952, 2002.

Rogge, W. F., Hildemann, L. M., Mazurek, M. A., Cass, G. R., and Simoneit, B. R. T.: Sources of Fine Organic Aerosol, 4. Particulate Abrasion Products from Leaf Surfaces of Urban Plants, Environ. Sci. Technol., 13, 2700-2711, 1993a.

Rogge, W. F., Hildemann, L. M., Mazurek, M. A., Cass, G. R., and Simoneit, B. R. T.: Sources of Fine Organic Aerosol, 5. NaturalGas Home Appliances, Environ. Sci. Technol., 13, 2736-2744, $1993 b$.

Sandradewi, J., Prévôt, A. S. H., Weingartner, E., Schmidhauser, R., Gysel, M., and Baltensperger, U.: A study of wood burning and traffic aerosols in an Alpine valley using a multi-wavelength, Aethalometer, Atmos. Environ., 42, 101-112, 2008a.

Sandradewi, J., Prévôt, A. S. H., Szidat, S., Perron, N., Alfarra, M. R., Lanz, V. A., Weingartner, E., and Baltensperger, U.: Using aerosol light absorption measurements for the quantitative determination of wood burning and traffic emission contributions to particulate matter, Environ. Sci. Technol., 42, 3316-3323, 2008 b.

Sandradewi, J., Prévót, A. S. H., Alfarra, M. R., Szidat, S., Wehrli, M. N., Ruff, M., Weimer, S., Lanz, V. A., Weingartner, E., Perron, N., Caseiro, A., Kasper-Giebl, A., Puxbaum, H., Wacker, L., and Baltensperger, U.: Comparison of several wood smoke markers and source apportionment methods for wood burning particulate mass, Atmos. Chem. Phys. Discuss., 8, 8091-8118, doi:10.5194/acpd-8-8091-2008, 2008c.

Schauer, J. J., Rogge, W. F., Hildemann, L. M., Mazurek, M. A., Cass, G. R., and Simoneit, B. R. T.: Source apportionment of airborne particulate matter using organic tracers, Atmos. Environ., 30, 3837-3855, 1996.

Sheesley, R. J., Schauer, J. J., Zheng, M., and Wang, B.: Sensitivity of molecular marker-based CMB models to biomass burning source profiles, Atmos. Environ., 39, 9050-9063, 2007.

Schneider, J., Weimer, S., Drewnick, F., Borrmann, S., Helas, G., Gwaze, P., Schmid, O., Andreae, M. O., and Kirchner, U.: Mass spectrometric analysis and aerodynamic properties of various types of combustion-related aerosol particles, Int. J. Mass Spectrom., 258, 37-49, 2006.

Schmidl, C., Marr, I. L., Caseiro, A., Kotianová, P., Berner, A., Bauer, H., Kasper-Giebl, A., and Puxbaum, H.: Chemical characterisation of fine particle emissions from wood stove combustion of common woods growing in mid-European Alpine regions, Atmos. Environ., 42, 126-141, 2008.

Shapiro, E. L., Szprengiel, J., Sareen, N., Jen, C. N., Giordano, M. R., and McNeill, V. F.: Light-absorbing secondary organic material formed by glyoxal in aqueous aerosol mimics, Atmos. Chem. Phys., 9, 2289-2300, doi:10.5194/acp-9-2289-2009, 2009.

Szidat, S., Jenk, T. M., Synal, H.-A., Kalberer, M., Wacker, L., Hajdas, I., Kasper-Giebl, A., and Baltensperger, U.: Contributions of fossil fuel, biomass burning, and biogenic emissions to carbonaceous aerosols in Zürich as traced by ${ }^{14} \mathrm{C}$, J. Geophys. Res., 111, D07206, doi:10.1029/2005JD006590, 2006.
Szidat, S., Prévôt, A. S. H., Sandradewi, J., Alfarra, M. R., Synal, Wacker, L., and Baltensperger, U.: Dominant impact of residential wood burning on particulate matter in Alpine valleys during winter, Geophys. Res. Lett., 34, L05820, doi:10.1029/2006GL028325, 2007.

Turpin, B. J. and Lim, H. J.: Species contribution to $\mathrm{PM}_{2.5}$ mass concentrations: revisiting common assumptions for estimating organic mass, Aerosol Sci. Tech., 35, 602-610, 2001.

Ulbrich, I. M., Canagaratna, M. R., Zhang, Q., Worsnop, D. R., and Jimenez, J. L.: Interpretation of organic components from Positive Matrix Factorization of aerosol mass spectrometric data, Atmos. Chem. Phys., 9, 2891-2918, doi:10.5194/acp-9-2891-2009, 2009.

Viana, M., Kuhlbusch, T. A. J., Querol, X., et al.: Source apportionment of particulate matter in Europe: A review of method and results, J. Aerosol Sci., 39, 827-849, 2008.

Weimer, S., Alfarra, M. R., Schreiber, D., Mohr, M., Prévôt, A. S. H., and Baltensperger, U.: Organic aerosol mass spectral signatures from wood-burning emissions: Influence of burning conditions and wood type, J. Geophys. Res., 113, D10304, doi:10.1029/2007JD009309, 2008.

Weimer, S., Mohr, C., Richter, R., Keller, J., Mohr, M., Prévôt, A. S. H., and Baltensperger, U.: Mobile measurements of aerosol number and volume size distributions in an Alpine valley: Influence of traffic versus wood burning, Atmos. Environ., 43, 624-630, 2009.

Weingartner, E., Saathoff, H., Schnaiter, M., Streit, N., Bitnar, B., and Baltensperger, U.: Absorption of light by soot particles: determination of the absorption coefficient by means of Aethalometers, J. Aerosol Sci., 34, 1445-1463, 2003.

Yang, M., Howell, S. G., Zhuang, J., and Huebert, B. J.: Attribution of aerosol light absorption to black carbon, brown carbon, and dust in China - interpretations of atmospheric measurements during EAST-AIRE, Atmos. Chem. Phys., 9, 2035-2050, doi:10.5194/acp-9-2035-2009, 2009.

Yttri, K. E., Dye, C., Braathen, O.-A., Simpson, D., and Steinnes, E.: Carbonaceous aerosols in Norwegian urban areas, Atmos. Chem. Phys., 9, 2007-2020, doi:10.5194/acp-9-2007-2009, 2009.

Zdráhal, Z., Oliveira, J., Vermeyelen, R., Clayes, M., and Maenhaut, W.: Improved method for quantifying levoglucosan and related monosaccharide anhydrides in atmospheric aerosols and application to samples from urban and tropical locations, Environ. Sci. Technol., 36, 747-753, 2002.

Zhang, Q., Alfarra, M. R., Worsnop, D. R., Allan, J. D., Coe, H., Canagaratna, M. R., and Jimenez, J. L.: Deconvolution and quantification of hydrocarbon-like and oxygenated organic aerosols based on aerosol mass spectrometry, Environ. Sci. Technol., 39, 4938-4952, 2005.

Zheng, M., Cass, G. R., Schauer, J. J., and Edgerton, E. S.: Source apportionment of $\mathrm{PM}_{2.5}$ in the southeastern United States using solvent-extractable organic compounds as tracers, Environ. Sci. Technol., 36, 2361-2371, 2002. 